\title{
Application of various methods for determination of the color of cocoa beans roasted under variable process parameters
}

\author{
Dorota Żyżelewicz $\cdot$ Wiesława Krysiak • Ewa Nebesny • \\ Grażyna Budryn
}

Received: 14 March 2013 / Revised: 29 October 2013 / Accepted: 30 October 2013 / Published online: 11 December 2013

(C) The Author(s) 2013. This article is published with open access at Springerlink.com

\begin{abstract}
Cocoa beans of Forastero variety from Togo were subjected to roasting under either constant or variable process parameters. The variable process parameters were roasting air flow rate, temperature and relative humidity. The color of roasted cocoa beans was determined by pigment extraction under various conditions followed by either their spectrophotometric assays or CIE L*a*b measurements. Also the Maillard compounds index and total polyphenols content correlated with progress of the browning of beans were determined. It was found that an increase in the roasting air relative humidity stimulated formation of brown pigments, while elevated temperature caused worsening of color parameters of roasted cocoa beans. The most suitable method of color characterization of roasted cocoa beans was found to be pigments extraction combined with either separation of their fractions or CIE $L^{*} a * b$ measurements. These assays revealed that cocoa beans roasted under variable roasting air flow rate were characterized by improved color parameters. The relatively simple and inexpensive CIE L*a*b measurements ensured fast analysis of color parameters, while total polyphenols in roasted cocoa beans were quickly estimated by using $\mathrm{F}-\mathrm{C}$ reagent. Furthermore, quantification of melanoid pigments in roasted cocoa beans can be based on determination of the index of nonenzymatic browning products content, which is relatively simple and inexpensive.
\end{abstract}

Keywords Cocoa bean $\cdot$ Roasting $\cdot$ Color $\cdot$ Variable parameters

D. Żyżelewicz $(\bowtie) \cdot$ W. Krysiak · E. Nebesny · G. Budryn Faculty of Biotechnology and Food Sciences, Institute of Chemical Technology of Food, Lodz University of Technology, Stefanowskiego 4/10 Street, 90-924 Lodz, Poland e-mail: dorota.zyzelewicz@p.lodz.pl

\section{Introduction}

Fermentation of cocoa beans followed by their roasting are the two key processes in chocolate manufacturing that decide of its quality. Physicochemical processes that are initiated during fermentation and continued during roasting cause a substantial change in contents of water, volatile acids, tannins and polyphenols as well as in the color, aroma and texture of cocoa beans [15, 18, 31]. Earlier investigations showed that roasting of unfermented cocoa beans did not result in formation of suitable precursors of taste and aroma. The roasted unfermented cocoa beans were deprived of the characteristic chocolate aroma and were bitter and astringent mainly due to high concentrations of polyphenols and tannins. The brown and purple color of the unfermented cocoa bean was attributed to the complex alteration products of catechin and tannin [2, $14,26]$.

During fermentation, polyphenols undergo polymerization reactions and form complexes with proteins yielding less water soluble derivatives, while anthocyans are hydrolyzed to anthocyanidins which undergo polymerization with simple catechins yielding tannins. Thus, fermentation leads to almost complete disappearance of anthocyans. In further steps of cocoa beans processing, the content of polyphenols continues to decrease. During drying, they are involved in reactions of enzymatic browning and the ultimate color of cocoa beans depends on drying method. During drying process, the characteristic brown color of not only cocoa beans but also of chocolate is developed due to the enzymatic oxidation of polyphenols. Drying rate is very important for the cocoa beans' quality. Too fast drying rate would result in high acidity (retaining an excessive amount of acids, mainly acetic acid), while too slow drying rate would result in low acidity, poorer color and high presence 
of molds [4, 12, 20, 29]. Roasting brings about further decrease in catechin and proanthocyanidin concentrations because of their reactions with proteins, products of their hydrolysis, amino acids, polysaccharides and Maillard reactions products yielding insoluble complexes. Although the nutritive value of cocoa beans is diminished due to the decrease in polyphenols content, their taste attributes are improved and their color is changed into dark brown $[6,7$, 19-21, 23, 27, 31].

The color is one of the most important physicochemical properties of roasted cocoa beans because it affects the quality of products derived from this commodity. Brown color is preferred to red-violet [30]. This parameter depends not only on contents of polyphenols and anthocyans and their derivatives but also on the presence of Maillard reactions products and products of starch dextrinization.

Maillard reactions which are reactions of nonenzymatic browning occurring in foods during thermal processing (also in cocoa beans) or long-term storage give rise to either positive or negative effects. Reactions between sugars and amino acids and proteins lead to degradation of essential amino acids, reduction in protein digestibility, inactivation of enzymes and lower susceptibility of proteins to proteolysis. Products of these reactions have either cancerogenic and mutagenic properties or display antioxidant and antibacterial activities that may positively affect human health. Reactions of cyclization, dehydration and condensation in the ultimate stage of Maillard processes yield both low molecular weight pigments and high molecular weight colored substances such as melanoidins [19].

The color of roasted cocoa beans can be determined by various methods such as the colorimetric CIE $\mathrm{L}^{*} \mathrm{a} * \mathrm{~b}$ method [18], pigment extraction, e.g., the assay of chocolate brown pigment $\mathrm{N}$ [22], extraction of pigments followed by separation of 3 principal fractions and determination of their concentration by colorimetric method [5] or spectrophotometric measurements of brown pigments in ethanol extracts $[13,18]$ or water extracts [6]. Also indices of pigments concentration such as the index of Maillard reactions products, which is determined spectrophotometrically [32] or total polyphenols content [10], are estimated.

Literature survey shows that earlier investigations focused on the effect of selected roasting parameters such as temperature or additional pretreatment processes such as alkalization on the color of cocoa beans and related products such as powdered cocoa and cocoa liquor [6]. For instance, Krysiak [15] studied the influence of relative humidity of roasting air on composition of pigments which were quantified according to Bonvehi and Coll [5]. The dependence of roasted cocoa beans color on roasting air flow rate and variable process parameters (temperature, flow rate and relative humidity of roasting air) has not been hitherto described. The aim of the study was to investigate the influence of the variable roasting process parameters on the formation of cocoa bean color. Therefore, this publication presents results of the study in which cocoa beans were processed under alternate conditions and furthermore, some selected parameters (temperature, flow rate and relative humidity of roasting air) were irreversibly changed during this process.

\section{Materials and methods}

\section{Materials}

Cocoa beans of Forastero variety were cultivated in Togo, which is located in West Africa at Guinea Bay. Only medium size beans were selected and used in roasting experiments.

\section{Chemicals}

We used the following chemicals: ethanol (CHEMPUR, Piekary Śląskie, Poland), chydrochloric acid (CHEMPUR, Piekary Śląskie, Poland), methanol (CHEMPUR, Piekary Śląskie, Poland), Silicagel G (Fluka Chemie GmbH, Buchs, Switzerland), Silicagel 60G (Merck KgaA, Darmstadt, Germany), Polyclar AT (SERVA Electrophoresis GmbH, Heidelberg, Germany), formic acid (CHEMPUR, Piekary Śląskie, Poland), Folin-Ciocalteu reagent (POCH, Gliwice, Poland), sodium carbonate (CHEMPUR, Piekary Sląskie, Poland).

\section{Experiments}

\section{Roasting}

Roasting processes were conducted in a laboratory convective roasting tunnel with forced air circulation and regulated air temperature $(T)$, flow rate $(v)$ and relative humidity $(\mathrm{RH})$. The $\mathrm{RH}$ was regulated using a steam generator both before thermal processing and during this process. All changes in roasting parameters were done after the first 15 min of thermal processing. Samples of raw fermented cocoa beans ( $200 \mathrm{~g}$ each) were put through inlet funnels on a tray made from metal grid. Roasting processes were terminated when water content in the samples

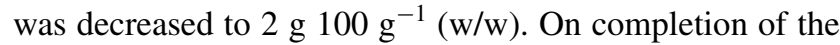
roasting process, the beans were immediately taken from the tunnel, cooled to approximately $20{ }^{\circ} \mathrm{C}$ using cold air and packed into tightly closed containers where they were kept for approximately $1 \mathrm{~h}$ to achieve the same temperature and humidity level in all the beans. Then they were subjected to husk removal, grinding in a laboratory mill and analyses. In this study, the cocoa beans were convectively roasted at temperatures of 135 or $150{ }^{\circ} \mathrm{C}$ using air 
with two different values of relative humidity such as dry

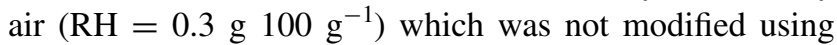
steam generator and air with a higher relative humid-

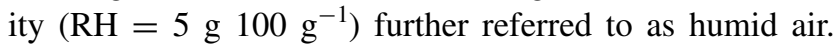
Application of roasting air with the higher relative humidity made the roasting process longer ( $\mathrm{t}$ ). Roasting was conducted at 2 air flow rates: $v=1 \mathrm{~m} \mathrm{~s}^{-1}$ or $v=0.5 \mathrm{~m} \mathrm{~s}^{-1}$, which were selected based on results obtained by Krysiak et al. [17] who investigated the effect of roasting parameters on selected attributes of roasted cocoa beans such as volatile acidity, total acidity and water content and determined the kinetics of changes in these attributes and roasting rates. Roasting processes were conducted in triplicate for each variant of roasting conditions. The control sample was raw cocoa bean. Variants of roasting conditions (constant and variable) tested in this study are presented below and numbered using Roman numeral.

Roasting under constant conditions

$$
\begin{aligned}
& \mathrm{I}-T=135^{\circ} \mathrm{C}, v=1 \mathrm{~m} \mathrm{~s}^{-1}, \mathrm{RH}=0.3 \mathrm{~g} 100 \mathrm{~g}^{-1}
\end{aligned}
$$

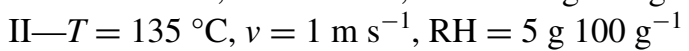

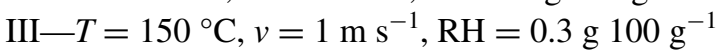

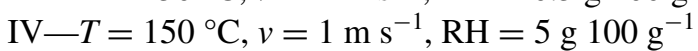

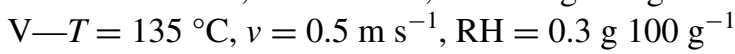

$$
\begin{aligned}
& \mathrm{VI}-T=135^{\circ} \mathrm{C}, v=0.5 \mathrm{~m} \mathrm{~s}^{-1}, \mathrm{RH}=5 \mathrm{~g} 100 \mathrm{~g}^{-1}
\end{aligned}
$$

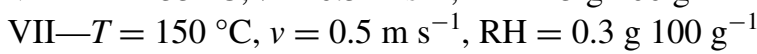

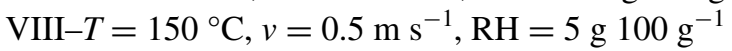

Roasting under variable conditions-variable air flow rate

IX- $T=135{ }^{\circ} \mathrm{C}, v_{1}=1 \mathrm{~m} \mathrm{~s}^{-1}-t_{1}=15 \mathrm{~min}$, and then

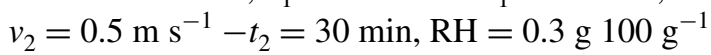

$\mathrm{X}-T=135{ }^{\circ} \mathrm{C}, v_{1}=1 \mathrm{~m} \mathrm{~s}^{-1}-t_{1}=15 \mathrm{~min}$, and then

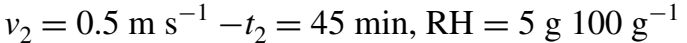

$\mathrm{XI}-T=150{ }^{\circ} \mathrm{C}, v_{1}=1 \mathrm{~m} \mathrm{~s}^{-1}-t_{1}=15 \mathrm{~min}$, and then

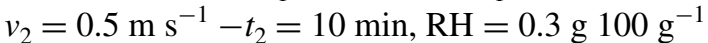

XII- $T=150{ }^{\circ} \mathrm{C}, v_{1}=1 \mathrm{~m} \mathrm{~s}^{-1}-t_{1}=15 \mathrm{~min}$, and then $v_{2}=0.5 \mathrm{~m} \mathrm{~s}^{-1}-t_{2}=15 \mathrm{~min}, \mathrm{RH}=5 \mathrm{~g} 100 \mathrm{~g} \mathrm{~g}^{-1}$

XIII $-T=135{ }^{\circ} \mathrm{C}, v_{1}=0.5 \mathrm{~m} \mathrm{~s}^{-1}-t_{1}=15 \mathrm{~min}$, and

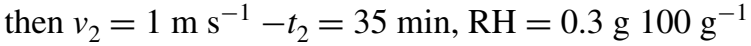
$\mathrm{XIV}-T=135{ }^{\circ} \mathrm{C}, v_{1}=0.5 \mathrm{~m} \mathrm{~s}^{-1}-t_{1}=15 \mathrm{~min}$, and then $v_{2}=1 \mathrm{~m} \mathrm{~s}^{-1}-t_{2}=45 \mathrm{~min}, \mathrm{RH}=5 \mathrm{~g}^{\circ} 00 \mathrm{~g} \mathrm{~g}^{-1}$ $\mathrm{XV}-T=150{ }^{\circ} \mathrm{C}, v_{1}=0.5 \mathrm{~m} \mathrm{~s}^{-1}-t_{1}=15 \mathrm{~min}$, and

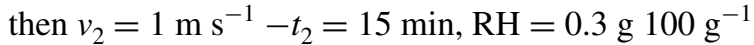
$\mathrm{XVI}-T=150{ }^{\circ} \mathrm{C}, v_{1}=0.5 \mathrm{~m} \mathrm{~s}^{-1}-t_{1}=15 \mathrm{~min}$, and then $v_{2}=1 \mathrm{~m} \mathrm{~s}^{-1}-t_{2}=15 \mathrm{~min}, \mathrm{RH}=5 \mathrm{~g} 100 \mathrm{~g}^{-1}$

Roasting under variable conditions-variable air temperature

XVII- $T_{1}=135{ }^{\circ} \mathrm{C}-t_{1}=15 \mathrm{~min}$, and then $T_{2}=150^{\circ} \mathrm{C}$

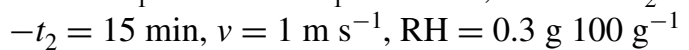

XVIII- $T_{1}=135{ }^{\circ} \mathrm{C}-t_{1}=15 \mathrm{~min}$, and then $T_{2}=150{ }^{\circ} \mathrm{C}-t_{2}=20 \min , v=1 \mathrm{~m} \mathrm{~s}^{-1}$, $\mathrm{RH}=5 \mathrm{~g} 100 \mathrm{~g}^{-1}$

XIX- $T_{1}=150{ }^{\circ} \mathrm{C}-t_{1}=15 \mathrm{~min}$, and then $T_{2}=135{ }^{\circ} \mathrm{C}$

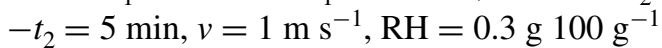

$\mathrm{XX}-T_{1}=150{ }^{\circ} \mathrm{C}-t_{1}=15 \mathrm{~min}$, and then $T_{2}=135{ }^{\circ} \mathrm{C}$

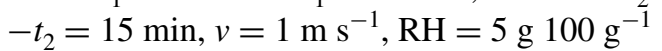

Roasting under variable conditions_-variable air relative humidity

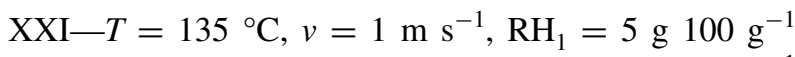
$-t_{1}=15 \mathrm{~min}$, and then $\mathrm{RH}_{2}=0.3 \mathrm{~g} 100 \mathrm{~g}^{-1}$ $-t_{2}=30 \mathrm{~min}$

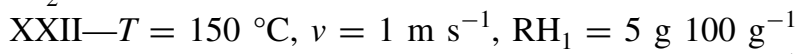
$-t_{1}=15 \mathrm{~min}$, and then $\mathrm{RH}_{2}=0.3 \mathrm{~g} 100 \mathrm{~g}^{-1}$ $-t_{2}=15 \mathrm{~min}$

Methods

\section{Dry mass content}

The dry mass content was determined by drying $4 \mathrm{~g}$ sample of ground cocoa beans at $103{ }^{\circ} \mathrm{C}$ for $16 \mathrm{~h}$ according to $\mathrm{PN}$ A-76101:1998 [25].

The color of roasted cocoa beans was estimated by pigment extraction and CIE $L * a * b$ method. Also Maillard reaction products index and total polyphenols were determined.

\section{Determination of color by extraction}

The color was determined according to Lee et al. [18]. A sample of ground cocoa beans $(1 \mathrm{~g})$ was suspended in

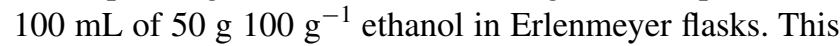
suspension was subjected to two-step extraction under the following conditions:

Variant I: Mixing for $5 \mathrm{~min}$ at room temperature in an ultra-sound bath followed by 10-min incubation at room temperature in an orbital shaker at $170 \mathrm{rpm}$. Resulting extract was filtered through blotting paper. The filtrate was diluted with

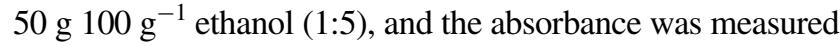
at $420 \mathrm{~nm}$ using UV/VIS Hitachi U-2800A spectrophotometer (Hitachi High-Technologies Corporation, Tokyo, Japan). The result was expressed in absorbance units (OD).

Variants II and III are modifications of Lee, Yoo, Lee, Kwon and Pyun methods [18]. In the second step of extraction, it means after 5 min sonication:

- the sample was incubated for $1 \mathrm{~h}$ at room temperature and at $170 \mathrm{rpm}$ in variant II,

- the sample was incubated for $1 \mathrm{~h}$ at $60{ }^{\circ} \mathrm{C}$ in a water bath at $170 \mathrm{rpm}$ in variant III. 
The extracts were filtered and further processed as in variant I.

\section{Determination of color and pigment fractions}

The color and pigment fractions were determined in triplicate according to Bonvehi and Coll [5]. The brown and red pigments (products of anthocyan conversion) were determined based on measurements of absorbance at 460 and $525 \mathrm{~nm}$, respectively.

Brown pigments were extracted at room temperature from $2 \mathrm{~g}$ samples of ground nibs of cocoa beans with $50 \mathrm{~mL}$ of $12 \mathrm{M} \mathrm{HCl} / \mathrm{CH}_{3} \mathrm{OH}(1 \mathrm{~mL} 12 \mathrm{M} \mathrm{HCl}+999 \mathrm{~mL}$ $\mathrm{CH}_{3} \mathrm{OH}$ ) for $45 \mathrm{~min}$. The extracts were filtered through Whatman 541 filter paper. Filtrate aliquots $(4 \mathrm{~mL})$ were placed in $25-\mathrm{mL}$ volumetric flasks, and their volume was filled with the extracting solvent $\left(12 \mathrm{M} \mathrm{HCl} / \mathrm{CH}_{3} \mathrm{OH}\right)$. The absorbance of diluted filtrate samples was measured at 460 and $525 \mathrm{~nm}$ using UV/VIS Hitachi U-2800A spectrophotometer (Hitachi High-Technologies Corporation, Tokyo, Japan) against the solvent $\left(12 \mathrm{M} \mathrm{HCl} / \mathrm{CH}_{3} \mathrm{OH}\right)$. The results were expressed on dry mass basis of raw or roasted cocoa beans, and the ratio $\mathrm{OD}_{460} / \mathrm{OD}_{525}$ was calculated. For good quality, properly fermented and roasted cocoa beans, this ratio is $\geq 1$ which corresponds to lower content of red pigments.

An important marker of the quality of roasted cocoa beans, in terms of their color, is the content of derivatives of anthocyans and hydroxycyanic acid (F1), red pigments (F2) and yellow and brown pigments (F3). All these pigment fractions were separated by liquid chromatography by using a column $(1.5 \mathrm{~cm}$ in diameter) packed with a blend (1.5 g) of Silicagel G, Silicagel 60G and Polyclar AT mixed in a proportion $2: 14: 4$. An aliquot $(2 \mathrm{~mL})$ of extract filtrate (extracted with $12 \mathrm{M} \mathrm{HCl} / \mathrm{CH}_{3} \mathrm{OH}$ ) was applied to the column, and pigment fractions were eluted with the following solvents $(25 \mathrm{~mL}$ each) used in the following order:

- anthocyan monomers: $12 \mathrm{M} \mathrm{HCl} / \mathrm{CH}_{3} \mathrm{OH}$

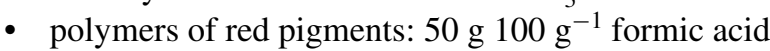

- polymers of yellow pigments: pure formic acid.

The eluates were collected in $25-\mathrm{mL}$ volumetric flasks, and their absorbance was measured at $525 \mathrm{~nm}$ versus

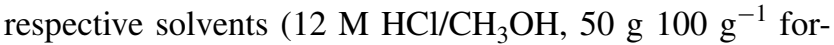
mic acid, pure formic acid). The content of each pigment fraction was calculated and expressed on dry mass basis of raw or roasted cocoa beans. Results of this assay were expressed as F1/F3 ratio, which should not excess 0.3 for good quality cocoa beans (in terms of color).
Color measurements in CIE $L * a * b *$ system

The color was determined using a trichromatic reflection colorimeter Konica Minolta CR-400 with Spectra Magic NX 1.3 software (Konica Minolta Sensing INC., Osaka, Japan). The results were expressed in accordance with CIE $\mathrm{L}^{*} \mathrm{a} * \mathrm{~b}$ system (D65 illuminant and $10^{\circ}$ viewing angle). The measurements were made with an 8-mm-diameter diaphragm inset with optical glass. Prior to the measurements, the equipment was calibrated using a standard white tile.

Color parameters, i.e., the brightness $\mathrm{L}^{*}$ (from 0-black to 100 -white), $\mathrm{a}^{*}$ (from $(-50)$ green to 50 -red), $\mathrm{b}^{*}$ (from (-50)-blue to 50-yellow) and $\mathrm{dE}$ value, equal to the square root of $\left[\left(\mathrm{dL}^{*}\right)^{2}+\left(\mathrm{da}^{*}\right)^{2}+\left(\mathrm{db}^{*}\right)^{2}\right]$, characterizing the total change of color were measured.

The color of ground cocoa beans samples was measured in triplicate at several points of each sample.

The obtained values were equivalent to the total color difference that is obvious or not for the human eye according to Bodart, de Peñarada, Deneyer and Flamant [3]:

$\mathrm{dE}^{*}<1$ color differences are not obvious for the human eye

$1<\mathrm{dE}^{*}<3$ minor color differences could be appreciated by the human eye depending of the hue

$\mathrm{dE}^{*}>3$ color differences are obvious for the human eye.

\section{Determination of the index of Maillard reactions products (MR index)}

The index was estimated by a spectrophotometric method as described by Yen, Wang, Chang and Duh [32].

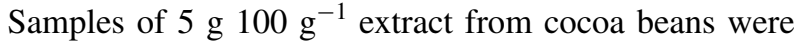
prepared by treatment of ground nibs of cocoa beans $(15.17 \mathrm{~g})$ with $87.5 \mathrm{~g}$ of boiling distilled water for $5 \mathrm{~min}$ with intermittent mixing. Resulting extracts were filtered and diluted with distilled water (1:4). Their absorbance was measured at $420 \mathrm{~nm}$ using a two-beam UV/VIS Hitachi U-2800A spectrophotometer (Hitachi High-Technologies Corporation, Tokyo, Japan).

The index of Maillard reactions products was calculated as follows:

MR index $=\mathrm{A}_{420}^{\mathrm{x}} 5^{\mathrm{x}} \mathrm{P}^{-1}$,

where $\mathrm{A}_{420}$ - absorbance, $\mathrm{P}$-percentage content (w/w) of solid substance in a tested sample.

\section{Total polyphenols}

Total polyphenols were assayed according to Fogliano and Verde [10]. 


\section{Quantification of total polyphenols}

Samples of ground cocoa beans $(1 \mathrm{~g})$ were weighed with the precision of $0.0001 \mathrm{~g}$ and placed in $100-\mathrm{mL}$ volumetric flasks. Polyphenols were extracted with acidi-

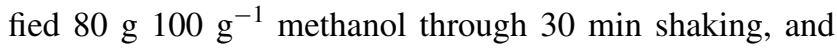
the extracts were filtered. Aliquots of resulting filtrates $(0.1 \mathrm{~mL})$ were placed in $50-\mathrm{mL}$ volumetric flasks and mixed for $1 \mathrm{~min}$ with portions of distilled water $(4.2 \mathrm{~mL})$ and $\mathrm{F}-\mathrm{C}$ reagent $(0.5 \mathrm{~mL})$. Then $1 \mathrm{~mL}$ of $80 \mathrm{~g} 100 \mathrm{~g}^{-1}$ sodium carbonate was added to each flask, and they were filled to $50 \mathrm{~mL}$ with distilled water. The samples were incubated in the darkness for $2 \mathrm{~h}$, and their absorbance was measured at $760 \mathrm{~nm}$ using a two-beam UV/VIS Hitachi U-2800A spectrophotometer (Hitachi High-Technologies Corporation, Tokyo, Japan).

\section{Standard curve}

A portion of gallic acid (2.4 mg) was dissolved (in 100-

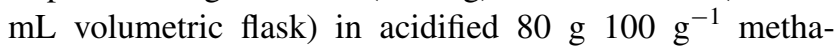
nol. Aliquots of this stock solution $(0.1,0.2,0.3,0.4,0.5$, $0.6,0.7,0.8,0.9$ and $1.0 \mathrm{~mL}$ ) were transferred to $50-\mathrm{mL}$ volumetric flasks and mixed for $1 \mathrm{~min}$ with $0.5 \mathrm{~mL}$ portions of Folin-Ciocalteu $(\mathrm{F}-\mathrm{C})$ reagent. Then $1 \mathrm{~mL}$ ali-

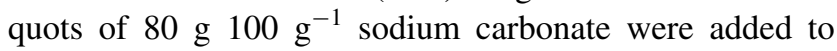
each flask, the volume of each sample was filled to $50 \mathrm{~mL}$ with distilled water, and they were incubated for $2 \mathrm{~h}$ in the darkness. The absorbance of the standard samples was measured at $760 \mathrm{~nm}$ using a two-beam UV/VIS Hitachi U-2800A spectrophotometer (Hitachi High-Technologies Corporation, Tokyo, Japan). Results of these measurements were used to plot the standard curve $A_{760}=f$ (gallic acid content $\mathrm{mg}^{\mathrm{x}} 50 \mathrm{~mL}^{-1}$ ) with the equation $\mathrm{y}=6.4556 \mathrm{x}$. The regression equation of the standard curve was used to calculate the concentration of total polyphenols in the studied samples.

Total polyphenols (g $100 \mathrm{~g} \mathrm{~s} \cdot \mathrm{s} .{ }^{-1}$ ) were calculated from the formula:

$\mathrm{Y}=\mathrm{A}\left(6.4556^{\mathrm{x}} \mathrm{m}^{\mathrm{x}} \text { s.s. }\right)^{-1 \mathrm{x}} 100$

where A-absorbance, $\mathrm{m}$-sample mass (g), s.s.—solid

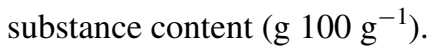

\section{Statistical analysis of the results}

Analyses and experiments were carried out in triplicate starting from cocoa bean roasting. The results of all assays were subjected to statistical analysis. It comprised of determination of average values as well as one-way ANOVA (analysis of variation) at the significance level of $p<0.05$.

\section{Results and discussion}

Estimation of the color by pigment extraction

Roasting processes were terminated when water content in

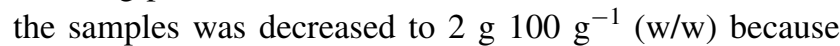
this water content in roasted cocoa beans was found to be optimal for its further processing such as grinding and fat pressing. The duration of roasting processes corresponding

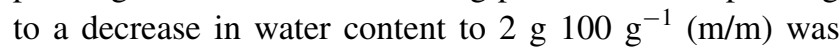
determined experimentally for this batch of cocoa beans. Although longer roasting processes leading to water content below $2 \mathrm{~g} 100 \mathrm{~g}^{-1}$ (w/w) are potentially beneficial in terms of chocolate manufacturing, they are more expensive (higher energy inputs during roasting, grinding of harder beans and fat pressing) and can cause burning of cocoa beans. The temperature and duration of cocoa beans roasting (which depends on the temperature) depend on their variety, form (whole beans, crushed bean or cocoa liquor), roaster construction and desired final result. Noble varieties of cocoa beans are usually roasted at lower temperatures to protect as much of desired aroma components as possible. Cocoa beans of Forastero variety are roasted in the temperature range $130-150{ }^{\circ} \mathrm{C}$, although $130{ }^{\circ} \mathrm{C}$ is thought to be too low. Therefore, in this study, the cocoa beans were convectively roasted at temperatures of 135 or $150{ }^{\circ} \mathrm{C}$ using air with two different values of relative humidity

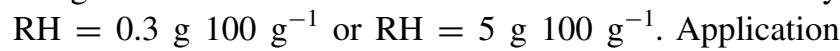
of roasting air with the higher relative humidity made the roasting process longer $(t)$.

Figure 1 presents the dependence of the color of cocoa beans expressed in absorbance units (OD) on conditions of roasting carried out at fixed process parameters, while Fig. 2 presents this dependence for variable process parameters.

Presented experimental results provide evidence that roasting parameters such as roasting air temperature, relative humidity and flow rate strongly affect the color of roasted cocoa beans. Also changes in roasting parameters during this process have an impact on the color. To determine the effect of constant roasting temperature on the intensity of brown color, the cocoa beans were roasted at 135 or $150{ }^{\circ} \mathrm{C}$. It was found that processing at the higher temperature $\left(150{ }^{\circ} \mathrm{C}\right)$ did not cause an increase in brown color intensity expressed in absorbance units (OD) (Fig. 1). Also an increase in the relative humid-

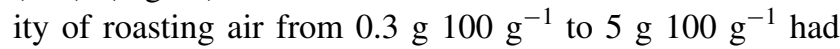
no effect on the intensity of brown color. When roasting was conducted at the lower air flow rate $\left(0.5 \mathrm{~m} \mathrm{~s}^{-1}\right)$,

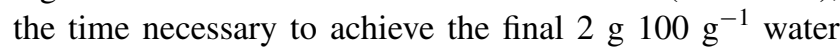
content in the nibs was longer and more brown pigments were generated (Fig. 1) with an exception of the samples roasted at $135{ }^{\circ} \mathrm{C}, \mathrm{RH}=5 \mathrm{~g} \cdot 100 \mathrm{~g}^{-1}$ and air flow 


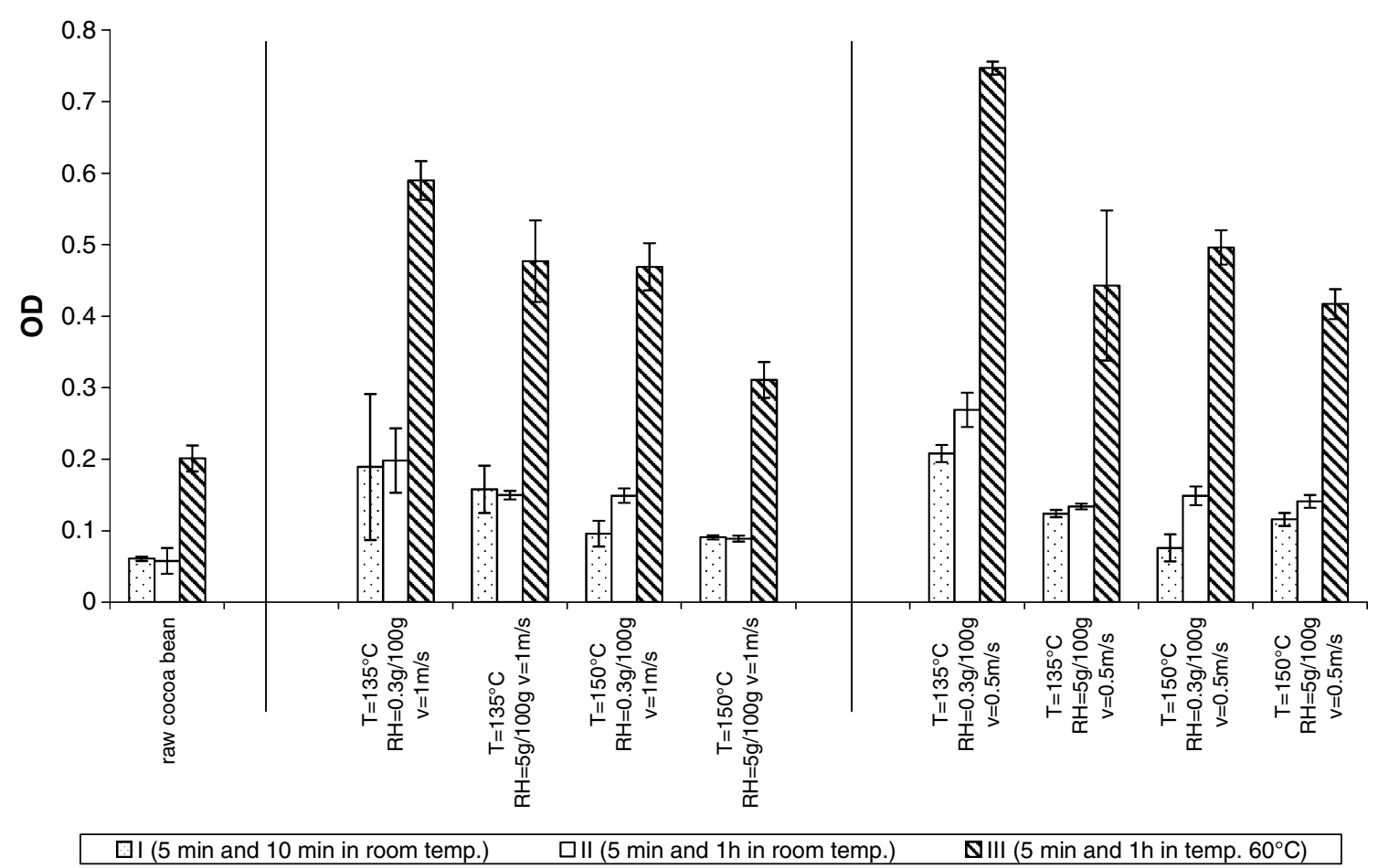

Fig. 1 The color of cocoa beans roasted under constant conditions; mean $\pm \mathrm{SD} ; n=9$

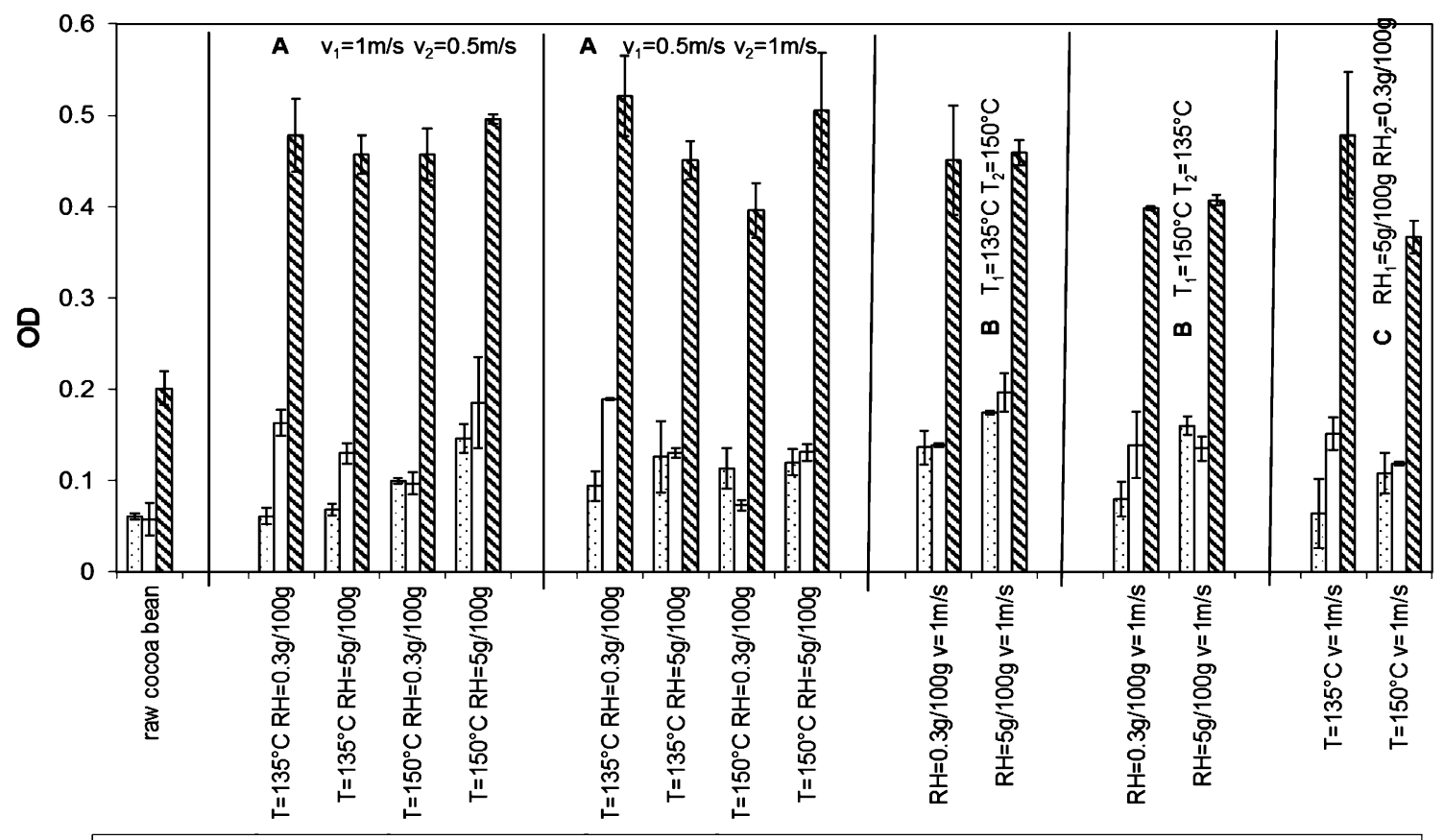

미 (5 min and $10 \mathrm{~min}$ in room temp.) ㅁll (5 min and $1 \mathrm{~h}$ in room temp.) $\mathbf{s} 11 \mathrm{l}\left(5 \mathrm{~min}\right.$ and $1 \mathrm{~h}$ in temp. $\left.60^{\circ} \mathrm{C}\right)$

Fig. 2 The color of cocoa beans roasted under conditions which were changed during the process of roasting in terms of the following parameters: $A$ roasting air flow rate, $B$ roasting air temperature, $C$ relative humidity of roasting air; mean $\pm \mathrm{SD} ; n=9$

rate of $0.5 \mathrm{~m} \mathrm{~s}^{-1}$, for which values of OD $(0.124$-variant I, 0.134-variant II, 0.443-variant III) were lower than OD values $(0.158$-variant I, 0.150 -variant II, 0.477-variant III) for samples roasted at the same temperature and RH but at the higher air flow rate of $1 \mathrm{~m} \mathrm{~s}^{-1}$. Processing of the samples roasted under the first conditions 
Table 1 Color parameters measured by CIE L*a*b* method in cocoa beans roasted under constant conditions

\begin{tabular}{|c|c|c|c|c|c|c|}
\hline Roasting process number & Roasting duration [min] & $\mathrm{L}^{*}$ & $a^{*}$ & $\mathrm{~b}^{*}$ & $\mathrm{dE}$ & Brightness (D65) \\
\hline Control & 0 & $34.69 \pm 0.15^{\mathrm{c}}$ & $5.52 \pm 0,02$ & $2.68 \pm 0.02$ & Standard & Standard \\
\hline I & 35 & $32.85 \pm 0.16^{\mathrm{bc}}$ & $11.20 \pm 0.35^{\mathrm{f}}$ & $4.32 \pm 0.06^{\mathrm{a}}$ & $6.19^{f}$ & 1.84 - darker \\
\hline II & 45 & $35.03 \pm 0.17^{\mathrm{c}}$ & $10.65 \pm 0.32^{\mathrm{ef}}$ & $5.51 \pm 0.13^{\mathrm{de}}$ & $5.87^{\mathrm{e}}$ & 0.33 - brighter \\
\hline III & 20 & $33.61 \pm 0.16^{\mathrm{bc}}$ & $7.29 \pm 0.08$ & $3.24 \pm 0.04$ & 2.15 & 1.09 - darker \\
\hline IV & 30 & $32.43 \pm 0.15^{\mathrm{a} b}$ & $9.42 \pm 0.18^{\mathrm{c}}$ & $4.17 \pm 0.07^{\mathrm{a}}$ & $4.75^{\mathrm{b}}$ & 2.27 - darker \\
\hline V & 45 & $37.20 \pm 0.26^{\mathrm{d}}$ & $11.28 \pm 0.34^{\mathrm{f}}$ & $6.68 \pm 0.21^{\mathrm{f}}$ & $6.62^{g}$ & 2.42 - darker \\
\hline VI & 90 & $33.84 \pm 0.17^{\mathrm{bc}}$ & $10.92 \pm 0.33^{\mathrm{ef}}$ & $4.65 \pm 0.08^{b}$ & $5.81^{\mathrm{de}}$ & 0.86 - darker \\
\hline VII & 30 & $37.03 \pm 0.24^{\mathrm{d}}$ & $10.38 \pm 0.30^{\mathrm{e}}$ & $6.42 \pm 0.20^{\mathrm{f}}$ & $6.56^{\mathrm{g}}$ & 2.34 - brighter \\
\hline VIII & 35 & $31.59 \pm 0.12^{\mathrm{ab}}$ & $7.93 \pm 0.11^{\mathrm{a}}$ & $2.48 \pm 0.02$ & 3.94 & 3.11 - darker \\
\hline
\end{tabular}

Different letters $(\mathrm{a}-\mathrm{g})$ or lack of them in a column corresponds to significant differences $(p<0.05), n=9$

I-VIII-numbers explained in paragraph 2.3. Experiments

$\left(T=135^{\circ} \mathrm{C}, \mathrm{RH}=5 \mathrm{~g} 100 \mathrm{~g}^{-1}, v=0.5 \mathrm{~m} \mathrm{~s}^{-1}\right.$-roasting No VI) was twice longer (until the water content in nibs

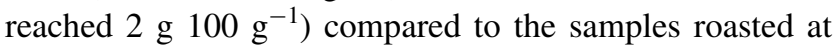
$v=1 \mathrm{~m} \mathrm{~s}^{-1}$ (roasting No II) (Table 1). The longer roasting time might negatively affect the color because of the disappearance of a part of brown pigments caused by burning of cocoa beans or polymerization of these pigments yielding water insoluble substances that cannot be extracted with water.

Although OD values were also affected by pigment extraction conditions, they clearly demonstrate the effect of process parameters on the color of roasted cocoa beans (Fig. 1). The tendency of changes in the intensity of brown color was best visible when the pigments were extracted for $1 \mathrm{~h}$ at $60^{\circ} \mathrm{C}$. The scarce literature data describing the influence of constant roasting conditions on the color of cocoa beans $[6,13,18,22]$ are consistent with our experimental results because they prove that process conditions affect formation of brown pigments. Bonvehi et al. [6] roasted either alkalized or nonalkalized cocoa powder derived from cocoa beans of various geographic origins at temperatures of 125 or $135{ }^{\circ} \mathrm{C}$. They found that formation of pigments was affected by alkalization, which influences the course of Maillard reactions through stimulation of reactions between amino acids and reducing sugars. Lee et al. [18] who roasted cocoa beans at temperatures ranging between 124 and $140{ }^{\circ} \mathrm{C}\left(124,128,132,136\right.$ and $\left.140{ }^{\circ} \mathrm{C}\right)$ observed that the intensity of brown color (OD) was decreased when the temperature was increased. Nebesny and Rutkowski [22] postulated that only roasting temperatures up to $135{ }^{\circ} \mathrm{C}$ cause advantageous changes in cocoa beans because these processes improve not only their taste and aroma but also brown color intensity. Furthermore, roasting at elevated temperatures (not exceeding $150{ }^{\circ} \mathrm{C}$ ) did not improve the quality of cocoa beans, but on the contrary, their taste and aroma as well as color were worse, probably due to the initiation of burning. The effect of variable process conditions on the color of roasted cocoa beans has not been hitherto described.

Our experimental results show that when the changing process parameter was the rate of flow of roasting air (either reduced from 1 to $0.5 \mathrm{~m} \mathrm{~s}^{-1}$ or increased from 0.5 to $1 \mathrm{~m} \mathrm{~s}^{-1}$ ), the higher intensity of brown pigments was observed in cocoa beans roasted at the higher relative air

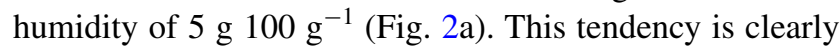
visible when the II or III variant of pigment extraction conditions was used. In variant I, the extraction was conducted for only $15 \mathrm{~min}$ ( 5 min sonication +10 min shaking) which seems to be insufficient for penetration of material particles by solvents and solubilization of brown pigments. The same relationship was observed when the variable roasting parameters were either temperature or relative humidity of roasting air. Pigment extraction according to variant I caused that the interplay between resulting OD values and roasting conditions was in some cases different from that observed when the extraction was conducted in accordance to variant II or III. When the variable process parameter was temperature, the intensity of brown color was higher when the cocoa beans were roasted for the first $15 \mathrm{~min}$ at $135{ }^{\circ} \mathrm{C}$ and then at $150{ }^{\circ} \mathrm{C}$ until water content in the nibs

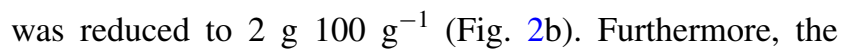
higher OD values were obtained when the humid air was used (variants II and III of pigment extraction conditions) that may be ascribed to the longer time of thermal processing (Table 3, No XVIII and XX), which was terminated at

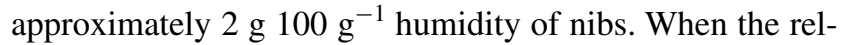
ative air humidity was decreased after the first $15 \mathrm{~min}$ from

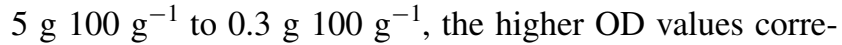
sponded to the lower roasting temperature $\left(135^{\circ} \mathrm{C}\right)$ like in the case of roasting under constant conditions.

The analysis of results of color determination through pigment extraction provides evidence that OD levels were similar for cocoa beans roasted under both constant and variable conditions. Among all tested samples, the highest 


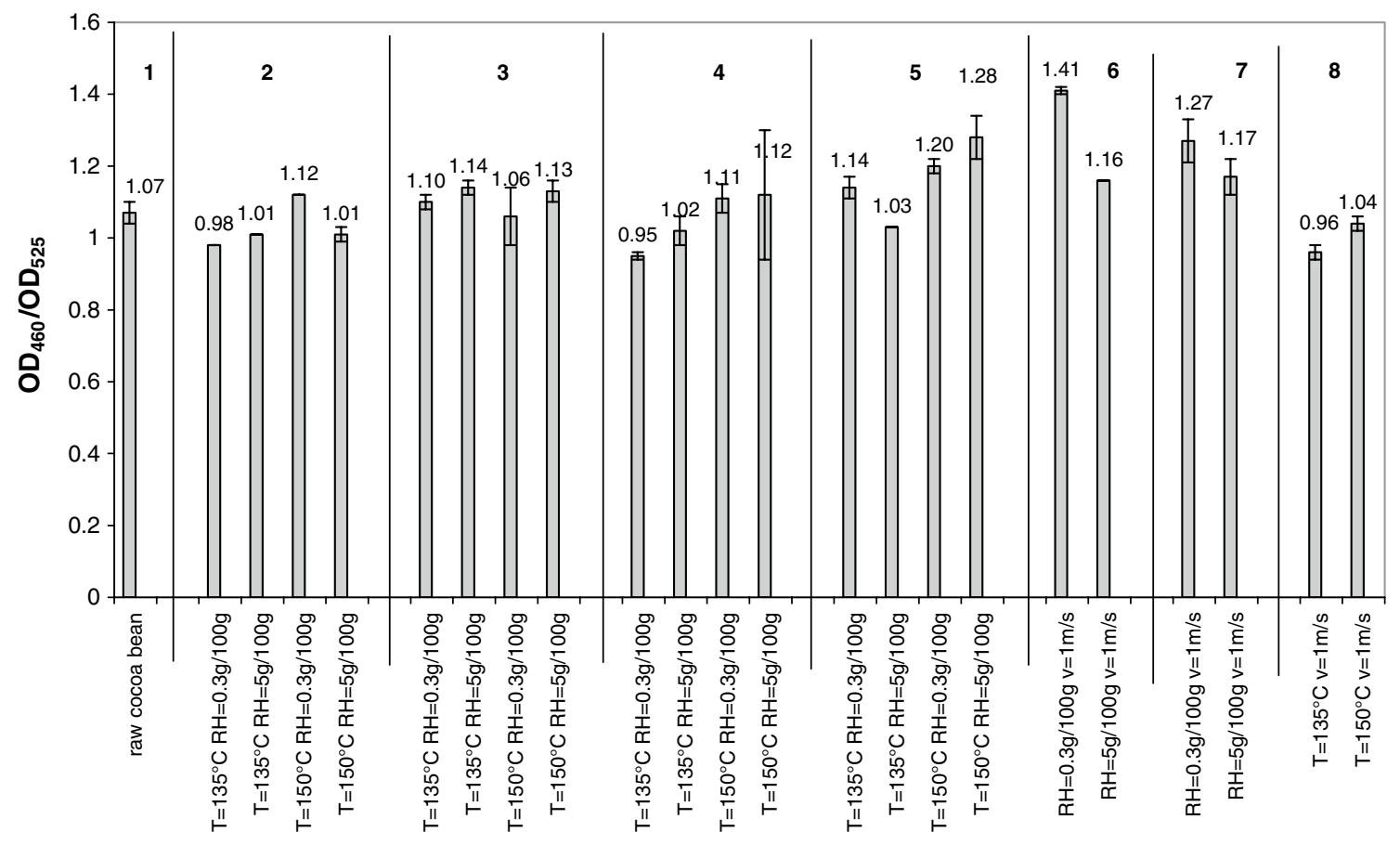

1: raw cocoa bean 2: $v=1 \mathrm{~m} / \mathrm{s} 3: \mathrm{v}=0.5 \mathrm{~m} / \mathrm{s} 4: \mathrm{v}_{1}=1 \mathrm{~m} / \mathrm{s} \mathrm{v}_{2}=0.5 \mathrm{~m} / \mathrm{s} 5: \mathrm{v}_{1}=0.5 \mathrm{~m} / \mathrm{s} \mathrm{v}_{2}=1 \mathrm{~m} / \mathrm{s} 6: \mathrm{T}_{1}=135^{\circ} \mathrm{C} \mathrm{T}_{2}=150^{\circ} \mathrm{C}$

7: $\mathrm{T}_{1}=150^{\circ} \mathrm{C} \mathrm{T}_{2}=135^{\circ} \mathrm{C} 8: \mathrm{RH}_{1}=5 \mathrm{~g} / 100 \mathrm{~g} \mathrm{RH}_{2}=0.3 \mathrm{~g} / 100 \mathrm{~g}$

Fig. 3 The effect of roasting conditions on the content of brown pigments in roasted cocoa beans (determined as $\mathrm{OD}_{460} / \mathrm{OD}_{525}$ index); mean $\pm \mathrm{SD} ; n=9$

OD values were observed in extracts obtained from cocoa beans roasted under constant conditions with dry air at $135{ }^{\circ} \mathrm{C}$ and air flow rate of $0.5 \mathrm{~m} \mathrm{~s}^{-1}(0.208$-variant I, 0.269-variant II, 0.747—variant III). When roasting was conducted under variable conditions, the highest intensity of brown color corresponded to roasting with dry air

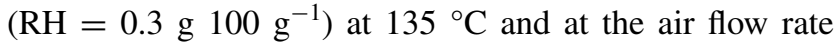
which was increased after the first $15 \mathrm{~min}$ from 0.5 to $1 \mathrm{~m} \mathrm{~s}^{-1}$ (0.189—variant II, 0.521—variant III) (Figs. 1, 2 parts A).

Determination of color and pigment fractions

Brown pigments (products of conversion of anthocyans) were quantified based on results of absorbance measurements at 460 and $525 \mathrm{~nm}$. The $\mathrm{OD}_{460} / \mathrm{OD}_{525}$ ratio for good quality, properly fermented and roasted cocoa beans is known to be $\geq 1$. This requirement was not fulfilled by the cocoa beans roasted under the following conditions:

- constant process parameters: $135^{\circ} \mathrm{C}, v=1 \mathrm{~m} \mathrm{~s}^{-1}$ and

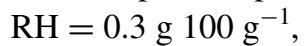

- variable process parameters: $T=135{ }^{\circ} \mathrm{C} v=1 \mathrm{~m} \mathrm{~s}^{-1}$

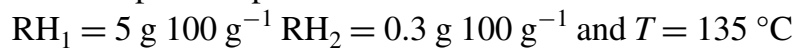
$v_{1}=1 \mathrm{~m} \mathrm{~s}^{-1} v_{2}=0.5 \mathrm{~m} \mathrm{~s}^{-1} \mathrm{RH}=5 \mathrm{~g} 100 \mathrm{~g}^{-1}$ (Fig. 3).
However, $\mathrm{OD}_{460} / \mathrm{OD}_{525}$ values corresponding to these 3 variants of roasting conditions were only slightly lower than 1 ( $0.98,0.95$ and 0.96 , respectively).

Values of $\mathrm{OD}_{460} / \mathrm{OD}_{525}$ for the tested variants of roasting conditions ranged between 0.95 and 1.41. The majority of them altered between approximately 1.1 and 1.2. These results are consistent with findings of Krysiak [15] who roasted cocoa beans from Ivory Coast under constant conditions. In opinion of Cros, Villeneuve and Vincent [8], these values indicate that the roasted cocoa beans are sufficiently brown. The highest concentration of brown pigments (1.41) was found in cocoa beans roasted with dry

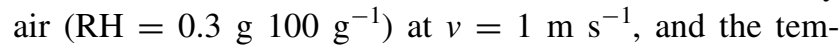
perature was ramped from 135 to $150{ }^{\circ} \mathrm{C}$. The relatively high $\mathrm{OD}_{460} / \mathrm{OD}_{525}$ values were also found for samples

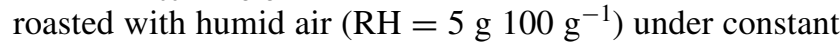
conditions. The opposite tendency was noticed when process parameters were variable because the higher $\mathrm{OD}_{460}$ l $\mathrm{OD}_{525}$ values corresponded to samples roasted with dry air

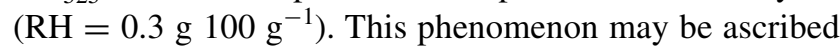
to the longer time of processing with the humid air. In some cases, this time is longer only by $5 \mathrm{~min}$ but it is sufficient to cause changes in red and brown pigments. The discrepancy between the results may be caused by different temperatures of cocoa beans contained in the same batch 
because according to Krysiak and Motyl-Patelska [16] the consequence of roasting under different flow rates and relative humidity of air is different temperature inside the nibs. Comparison of $\mathrm{OD}_{460} / \mathrm{OD}_{525}$ values for cocoa beans roasted under constant conditions at different relative humidity of air shows that the longer time of processing with humid air, which is necessary to achieve $2{\mathrm{~g} 100 \mathrm{~g}^{-1}}^{-1}$ humidity of nibs, results in formation of higher amounts of brown pigments. It can be caused by differences in water content and water activity of cocoa beans subjected to processing (unpublished data). Nonenzymatic browning reactions require a suitable water concentration in reaction medium. The comparison of $\mathrm{OD}_{460} / \mathrm{OD}_{525}$ values for cocoa beans roasted under constant conditions at the air flow rate of either 1 or $0.5 \mathrm{~m} \mathrm{~s}^{-1}$ shows that despite the longer processing at the lower air flow rate $\left(0.5 \mathrm{~m} \mathrm{~s}^{-1}\right)$, the values of $\mathrm{OD}_{460} / \mathrm{OD}_{525}$ were at the same level as those found for the samples roasted at $v=1 \mathrm{~m} \mathrm{~s}^{-1}$ and ranged between 0.98 and 1.14. Such results suggest that application of constant roasting parameters (within the range used in this and aforementioned studies) results in similar $\mathrm{OD}_{460} / \mathrm{OD}_{525}$ values despite slightly higher values of this ratio corresponding to roasting with humid air at a flow rate of $0.5 \mathrm{~m} \mathrm{~s}^{-1}$. However, the longer time of roasting under the latter conditions and minor increase in $\mathrm{OD}_{460} l$ $\mathrm{OD}_{525}$ value compared to results obtained when cocoa beans are processed with dry air at $v=1 \mathrm{~m} \mathrm{~s}^{-1}$ cause that from the economic point of view more advantageous is roasting with dry air flowing at the rate of $1 \mathrm{~m} \mathrm{~s}^{-1}$. Literature survey revealed that also Krysiak [15] who stud-

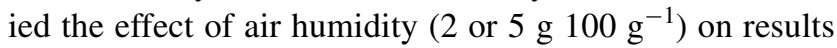
of cocoa beans roasting under constant conditions noticed the higher brown pigments content for dry air. However, Krysiak [15] roasted cocoa beans from the Ivory Coast and determined the impact of neither air flow rate nor variation in process parameters on their color. Krysiak found the correlation between roasting temperature and $\mathrm{OD}_{460} /$ $\mathrm{OD}_{525}$ ratio for these cocoa beans. Roasting at $150{ }^{\circ} \mathrm{C}$ gave rise to higher values of this ratio compared to roasting at either 135 or $110{ }^{\circ} \mathrm{C}$. In our work, samples of cocoa beans roasted under constant conditions were regarded as reference samples which were prepared to find effects caused by changes in process parameters during roasting. The correlation between roasting temperature and $\mathrm{OD}_{460} / \mathrm{OD}_{525}$ ratio was observed in only one case (roasting with dry air at $v=1 \mathrm{~m} \mathrm{~s}^{-1}$ ), while in the other cases, it was not found probably because of the different origin of cocoa beans (Togo) affecting their chemical composition. When roasting was conducted under variable conditions, the similar relationship was observed for the variable air flow rate $\left(1 \rightarrow 0.5 \mathrm{~m} \mathrm{~s}^{-1}\right.$ or $\left.0.5 \rightarrow 1 \mathrm{~m} \mathrm{~s}^{-1}\right)$ and relative humidity (Fig. 3). For comparison, the correlation between roasting temperature and the color of roasted hazelnuts was found by Demir et al. [9] and Özdemir and Devres [24] who found that temperature was the factor deciding of this color.

Our experiments revealed that concentrations of pigment fractions (F1, F2, F3) were highly variable and it was difficult to find any relationship between them and roasting conditions (Fig. 4). Pigment profiles, it means the quality and quantity of these substances, are determined by reactions taking place during roasting when some pigments almost disappear. Simultaneously, starch undergoes dextrinization. Reactions of polymerization and polycondensation generate compounds containing such functional groups such as methyl, carbonyl, hydroxyl, amine, amide, and indole as well as ester and ether bonds. Their consequence is the considerable decrease in the content of violet and red pigments and deeper, desired brown color. Highest concentrations of yellow and brown pigments (fraction F3) were found in cocoa beans roasted under variable air humidity and at $v=1 \mathrm{~m} \mathrm{~s}^{-1}$ and $135{ }^{\circ} \mathrm{C}\left(73.69 \mathrm{~g} 100 \mathrm{~g} \mathrm{~g}^{-1}\right.$ _Fig. 4) and at the variable rate of flow $\left(1 \rightarrow 0.5 \mathrm{~m} \mathrm{~s}^{-1}\right)$ of humid air $\left(\mathrm{RH}=5 \mathrm{~g}^{\left.100 \mathrm{~g}^{-1}\right)}\right.$ at the temperature of $150{ }^{\circ} \mathrm{C}$ (60.56 g $100 \mathrm{~g}^{-1}$-Fig. 4).

Roasting causes considerable changes in concentrations of fractions $\mathrm{F} 1$ and $\mathrm{F} 3$, and therefore, the ratio $\mathrm{F} 1 / \mathrm{F} 3$ is a marker that can be used to evaluate the progress of cocoa beans browning (Fig. 5). According to Cros, Villeneuve and Vincent [8] for good quality roasted cocoa beans, this ratio is $\leq 0.3$. This value was achieved when the cocoa beans were roasted under the following conditions:

- constant roasting conditions: $T=135{ }^{\circ} \mathrm{C} v=1 \mathrm{~m} \mathrm{~s}^{-1}$

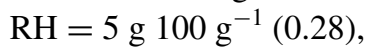

- variable conditions: $T=150{ }^{\circ} \mathrm{C} \mathrm{RH}=5 \mathrm{~g} 100 \mathrm{~g}^{-1}$ $v_{1}=1 \mathrm{~m} \mathrm{~s}^{-1}-t_{1}=15 \mathrm{~min}$, and then $v_{2}=0.5 \mathrm{~m} \mathrm{~s}-1$ $-t 2=15 \min (0.29), T=150{ }^{\circ} \mathrm{C} \mathrm{RH}=0.3 \mathrm{~g} 100 \mathrm{~g}-1$ $v 1=0.5 \mathrm{~m} \mathrm{~s}-1-t 1=15 \mathrm{~min}$, and then $v 2=1 \mathrm{~m} \mathrm{~s}-1-t 2=15 \min (0.25), T=150{ }^{\circ} \mathrm{C}$ $\mathrm{RH}=5 \mathrm{~g} 100 \mathrm{~g}-1 v 1=05 \mathrm{~m} \mathrm{~s}-1-t 1=15 \mathrm{~min}$, and then $v 2=1 \mathrm{~m} \mathrm{~s}-1-t 2=15 \min (0.29), T=135{ }^{\circ} \mathrm{C}$

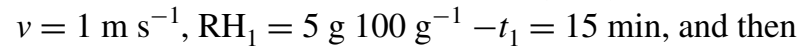

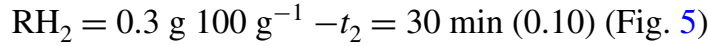

The lowest, it means the most advantageous F1/F3, value was achieved when cocoa beans were roasted at $135{ }^{\circ} \mathrm{C}$ and at variable relative air humidity. In general, variable process conditions were advantageous in terms of the browning level expressed as F1/F3.

\section{Color measurements in CIE L*a*b* system}

Results of measurements of color parameters such as $\mathrm{L}^{*}$, $a^{*}, b^{*}$ and $\mathrm{dE}$ (total difference of color that is obvious or not for the human eye) for cocoa beans roasted under 


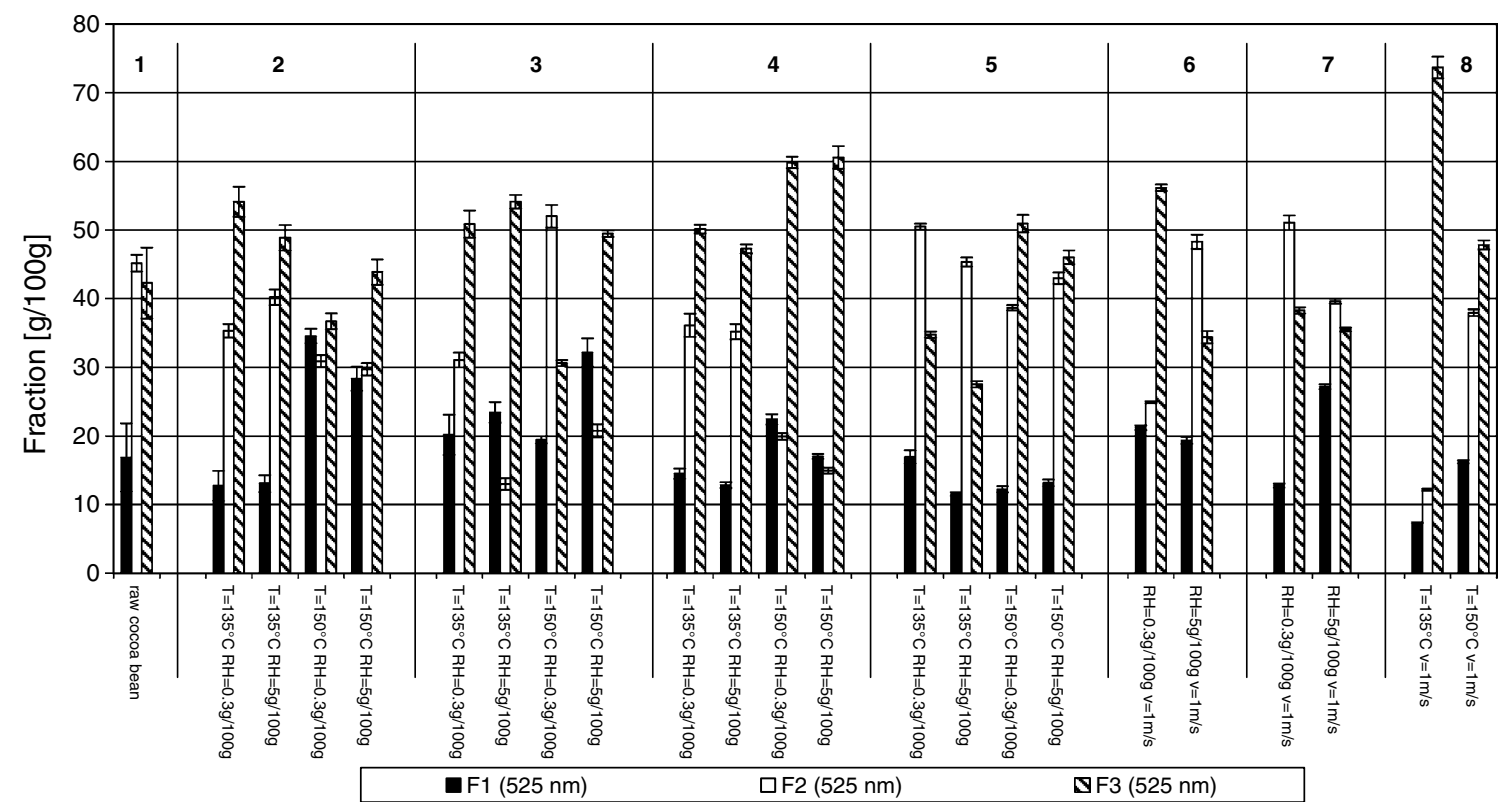

1: raw cocoa bean 2: $v=1 \mathrm{~m} / \mathrm{s}$ 3: $v=0.5 \mathrm{~m} / \mathrm{s} 4: v_{1}=1 \mathrm{~m} / \mathrm{s} \mathrm{v}_{2}=0.5 \mathrm{~m} / \mathrm{s} 5: v_{1}=0.5 \mathrm{~m} / \mathrm{s} v_{2}=1 \mathrm{~m} / \mathrm{s} 6: \mathrm{T}_{1}=135^{\circ} \mathrm{C} T_{2}=150^{\circ} \mathrm{C}$

7: $\mathrm{T}_{1}=150^{\circ} \mathrm{C} \mathrm{T}_{2}=135^{\circ} \mathrm{C}$ 8: $\mathrm{RH}_{1}=5 \mathrm{~g} / 100 \mathrm{~g} \mathrm{RH}_{2}=0.3 \mathrm{~g} / 100 \mathrm{~g}$

Fig. 4 Contents of pigments fractions in cocoa beans roasted under variable process parameters calculated based on measurements of absorbance at the wavelength of $525 \mathrm{~nm}$; mean $\pm \mathrm{SD} ; n=9$

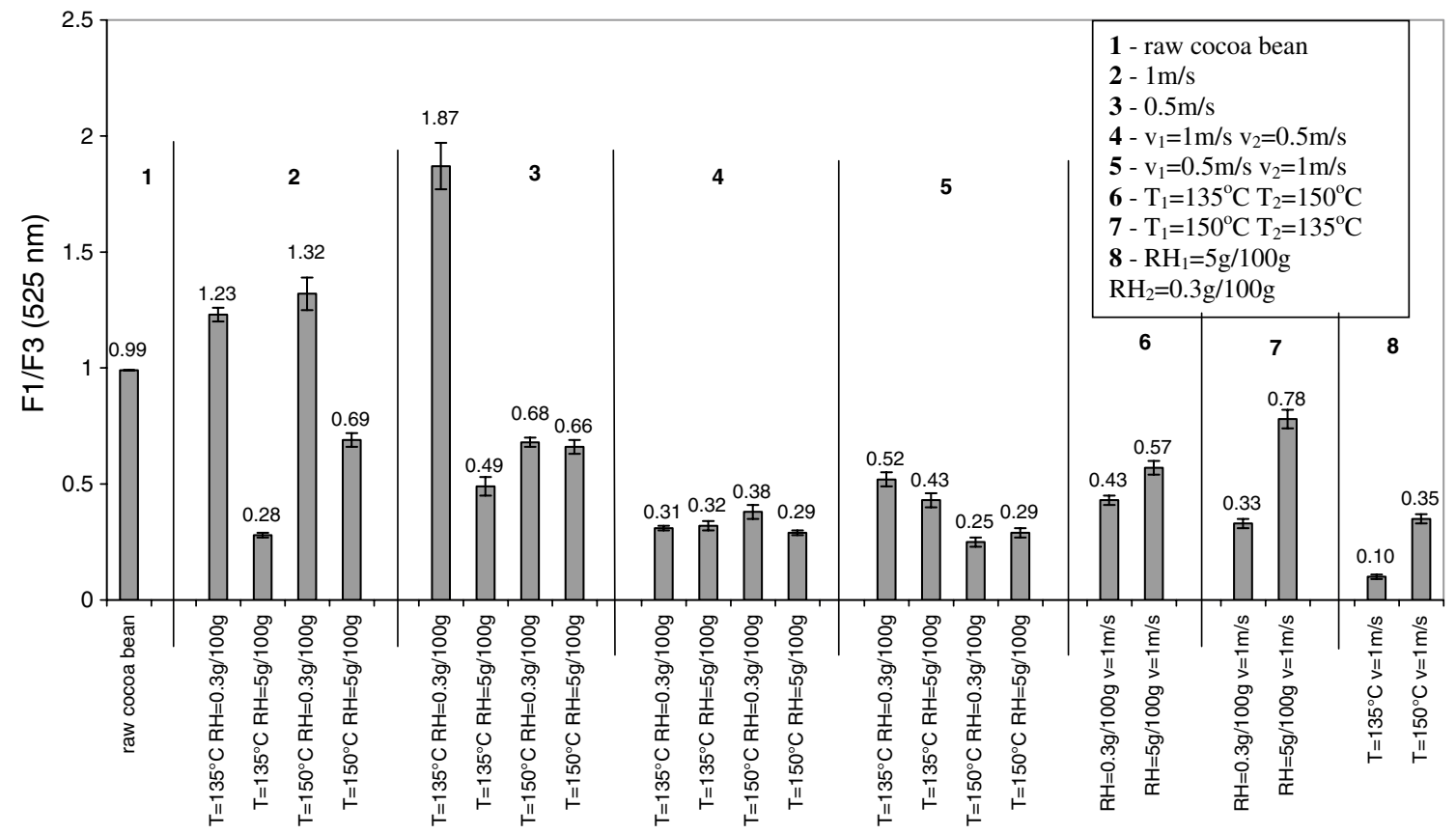

Fig. 5 The color of cocoa beans roasted under variable process parameters expressed as F1/F3 ratio; mean \pm SD; $n=9$

tested conditions are collected in Tables 1, 2, 3, 4. The color parameters are related to the browning reactions. According to Hawlader et al. [11] and Rocha and Morais
[28], who studied the color changes of minimally processed apples, a decrease in parameter $\mathrm{L}^{*}$ and an increase in $a^{*}$ value indicate to higher sample browning. Brightness 
Table 2 Color parameters measured by CIE L*a*b* method in cocoa beans roasted under variable air flow rate

\begin{tabular}{|c|c|c|c|c|c|c|}
\hline Roasting process number & Roasting duration [min] & $\mathrm{L}^{*}$ & $a^{*}$ & $b^{*}$ & $\mathrm{dE}$ & Brightness (D65) \\
\hline IX & 45 & $31.67 \pm 0.13^{\mathrm{a} b}$ & $8.73 \pm 0.14^{\mathrm{b}}$ & $2.94 \pm 0.03$ & $4.42^{\mathrm{a}}$ & 3.03 - darker \\
\hline $\mathrm{X}$ & 60 & $33.70 \pm 0.18^{b c}$ & $9.13 \pm 0.17^{\mathrm{bc}}$ & $4.72 \pm 0.08^{\mathrm{b}}$ & $4.26^{\mathrm{a}}$ & 0.99 - darker \\
\hline $\mathrm{XI}$ & 25 & $33.82 \pm 0.18^{\mathrm{bc}}$ & $11.42 \pm 0.34^{\mathrm{f}}$ & $5.63 \pm 0.14^{\mathrm{d}}$ & $6.65^{\mathrm{g}}$ & 0.88 - darker \\
\hline XII & 30 & $33.86 \pm 0.19^{b c}$ & $10.36 \pm 0.30^{\mathrm{d} \mathrm{e}}$ & $5.42 \pm 0.13^{\mathrm{d}}$ & $6.65^{\mathrm{g}}$ & 0.82 - darker \\
\hline XIII & 50 & $31.69 \pm 0.14^{\mathrm{ab}}$ & $9.23 \pm 0.18^{\mathrm{c}}$ & $3.79 \pm 0.02$ & $4.90^{b c}$ & 3.00 - darker \\
\hline XIV & 60 & $31.10 \pm 0.13^{\mathrm{a} b}$ & $8.09 \pm 0.12^{\mathrm{a}}$ & $5.33 \pm 0.11^{\mathrm{c}}$ & $5.15^{\mathrm{c}}$ & 3.59 - darker \\
\hline$X V$ & 30 & $32.85 \pm 0.16^{\mathrm{bc}}$ & $11.20 \pm 0.33^{\mathrm{f}}$ & $4.17 \pm 0.06^{\mathrm{a}}$ & $5.87^{\mathrm{e}}$ & 1.97 - darker \\
\hline XVI & 30 & $34.68 \pm 0.17$ & $12.49 \pm 0.39$ & $7.49 \pm 0.26$ & 8.47 & 0.01 - darker \\
\hline
\end{tabular}

Different letters $(\mathrm{a}-\mathrm{g})$ or lack of them in a column corresponds to significant differences $(p<0.05), n=9$

IX-XVI-numbers explained in paragraph 2.3. Experiments

Table 3 Color parameters measured by CIE L*a*b* method in cocoa beans roasted under variable air temperature

\begin{tabular}{|c|c|c|c|c|c|c|}
\hline Roasting process number & Roasting duration [min] & $\mathrm{L}^{*}$ & $a^{*}$ & $b^{*}$ & $\mathrm{dE}$ & Brightness (D65) \\
\hline XVII & 30 & $31.25 \pm 0.12^{\mathrm{a} b}$ & $8.00 \pm 0.10^{\mathrm{a}}$ & $2.68 \pm 0.01$ & $4.24^{\mathrm{a}}$ & 3.45 - darker \\
\hline XVIII & 35 & $32.59 \pm 0.15^{\mathrm{ab}}$ & $9.93 \pm 0.28^{\mathrm{d}}$ & $4.29 \pm 0.06^{\mathrm{a}}$ & $5.14^{\mathrm{c}}$ & 2.11 - darker \\
\hline XIX & 20 & $32.72 \pm 0.16^{\mathrm{b}}$ & $10.47 \pm 0.31^{\mathrm{e}}$ & $4.26 \pm 0.05^{\mathrm{a}}$ & $5.55^{\mathrm{d}}$ & 1.97 - darker \\
\hline $\mathrm{XX}$ & 30 & $34.50 \pm 0.29^{c}$ & $11.32 \pm 0.34^{\mathrm{f}}$ & $5.74 \pm 0.14^{\mathrm{e}}$ & $6.56^{\mathrm{g}}$ & 0.19 - darker \\
\hline
\end{tabular}

Different letters $(\mathrm{a}-\mathrm{g})$ or lack of them in a column corresponds to significant differences $(p<0.05), n=9$

XVII-XX-numbers explained in paragraph 2.3. Experiments

Table 4 Color parameters measured by CIE L*a*b* method in cocoa beans roasted under variable air relative humidity

\begin{tabular}{|c|c|c|c|c|c|c|}
\hline Roasting process number & Roasting duration [min] & $\mathrm{L}^{*}$ & $a^{*}$ & $b^{*}$ & $\mathrm{dE}$ & Brightness (D65) \\
\hline XXI & 45 & $33.39 \pm 0.16^{\mathrm{b}}$ & $10.81 \pm 0.33^{\mathrm{de}}$ & $5.08 \pm 0.11^{\mathrm{c}}$ & $5.95^{\mathrm{e}}$ & 1.31 - darker \\
\hline XXII & 30 & $34.50 \pm 0.29$ & $11.20 \pm 0.35^{\mathrm{e}}$ & $5.74 \pm 0.14^{\mathrm{d}}$ & $6.19^{\mathrm{e}}$ & 1.84 - darker \\
\hline
\end{tabular}

Different letters (b-e) or lack of them in a column corresponds to significant differences $(p<0.05), n=9$

XXI-XXII-numbers explained in paragraph 2.3. Experiments

analysis showed that the majority of roasted cocoa beans were darker than the raw ones, which were used as the reference in the experiments. Parameter $\mathrm{dE}$ was higher than 3 in almost all cases, and therefore, the change in color of roasted cocoa beans compared to raw, fermented ones was visible and obvious for the human eye with an exception of cocoa beans roasted with dry air under constant conditions at $150{ }^{\circ} \mathrm{C}$ and $v=1 \mathrm{~m} \mathrm{~s}^{-1}$, for which $\mathrm{dE}$ was only 2.15 . It means that they were only slightly darker than the raw cocoa beans. The relatively low value of $\mathrm{dE}$ corresponded to the relatively high value of $\mathrm{L}^{*}$ (one of the highest among tested samples). The highest $\mathrm{dE}$ value was observed for cocoa beans roasted at $150{ }^{\circ} \mathrm{C}$ with humid air

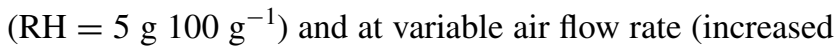
from 0.5 to $1 \mathrm{~m} \mathrm{~s}^{-1}$ (Table 2, No. XVI). For this sample, parameter $\mathrm{L}^{*}$ was at the same level as for the raw cocoa beans, while parameters $a^{*}$ and $b^{*}$ were substantially different. The latter roasted cocoa beans were characterized by the highest concentrations of yellow and red pigments among tested samples of roasted and raw cocoa beans. It was found that when roasting was carried out under variable conditions, an increase in temperature (at fixed relative humidity and flow rate of air) brought about a rise in concentrations of yellow and red pigments. In contrast, when roasting conditions were constant, the concentrations of these pigments were lower in cocoa beans processed at the higher process temperature $\left(150{ }^{\circ} \mathrm{C}\right)$ compared to those roasted at $135{ }^{\circ} \mathrm{C}$ (at fixed air flow rate and relative humidity). Application of humid air ( $\mathrm{RH}=5{\left.\mathrm{~g} 100 \mathrm{~g}^{-1}\right)}$ for roasting under constant conditions resulted in higher values of parameter $\mathrm{L}^{*}$ compared to roasting with dry

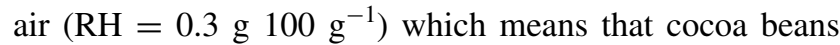
roasted at higher RH of air were darker. Lower $\mathrm{L}^{*}$ values did not correspond with higher values of $\mathrm{a}^{*}$, with an exception of cocoa beans roasted at $150{ }^{\circ} \mathrm{C}$ and $v=1 \mathrm{~m} \mathrm{~s}^{-1}$. The effect of air flow rate on color parameters was not observed. 


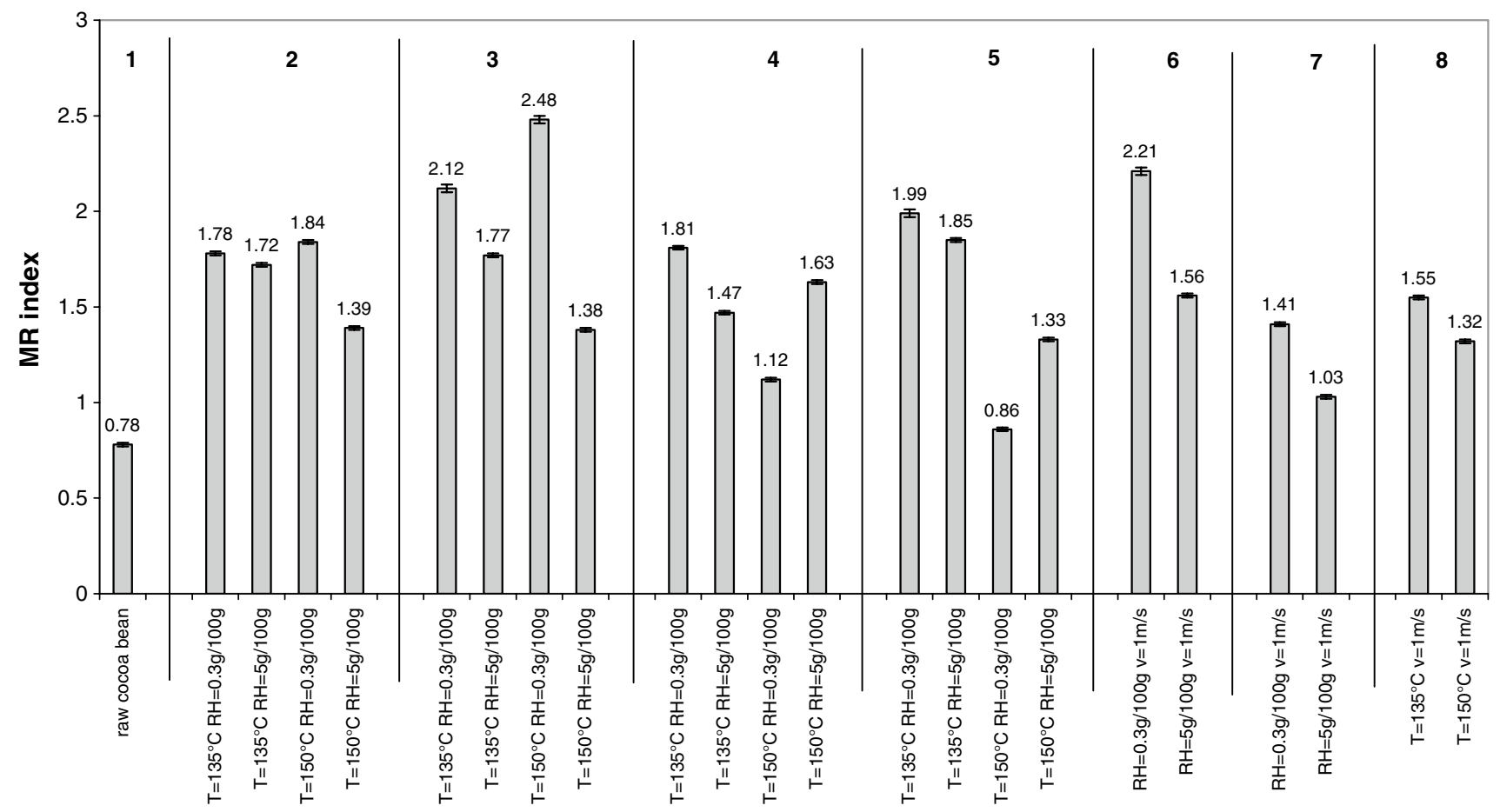

1: raw cocoa bean 2: $v=1 \mathrm{~m} / \mathrm{s}$ 3: $v=0.5 \mathrm{~m} / \mathrm{s} 4: v_{1}=1 \mathrm{~m} / \mathrm{s} \mathrm{v}_{2}=0.5 \mathrm{~m} / \mathrm{s} 5: v_{1}=0.5 \mathrm{~m} / \mathrm{s} v_{2}=1 \mathrm{~m} / \mathrm{s}: \mathrm{T}_{1}=135^{\circ} \mathrm{C} \mathrm{T}_{2}=150^{\circ} \mathrm{C}$

7: $\mathrm{T}_{1}=150^{\circ} \mathrm{C} \mathrm{T}_{2}=135^{\circ} \mathrm{C} 8: \mathrm{RH}_{1}=5 \mathrm{~g} / 100 \mathrm{~g} \mathrm{RH}_{2}=0.3 \mathrm{~g} / 100 \mathrm{~g}$

Fig. 6 The dependence of Maillard compounds index on conditions of cocoa beans roasting; mean \pm SD; $n=9$

When roasting was conducted under variable conditions, an increase in air RH caused a rise in parameter $\mathrm{L}^{*}$ as well as values of $a^{*}$ and $b^{*}$.

Reassuming, the deepest brown color of roasted cocoa beans from Togo (measured in CIE L*a*b* system) corresponding to the lowest value of parameter $\mathrm{L}^{*}$ was observed when the beans were processed with humid air at $135{ }^{\circ} \mathrm{C}$ and when the air flow rate was ramped from 0.5 to $1 \mathrm{~m} \mathrm{~s}^{-1}$. The highest concentrations of red, yellow and brown pigments were observed after roasting with humid air at $150{ }^{\circ} \mathrm{C}$ and growing air flow rate (from 0.5 to $1 \mathrm{~m} \mathrm{~s}^{-1}$ ) (Table 2).

\section{Determination of MR index}

For raw cocoa beans tested in this study, the index of Maillard reactions products (MR index) was 0.78 (Fig. 6).

This index was higher for cocoa beans roasted with dry air under constant conditions, in particular when $v=0.5 \mathrm{~m} \mathrm{~s}^{-1}$ (Fig. 6). The latter were processed longer than cocoa beans treated with air flowing at $v=1 \mathrm{~m} \mathrm{~s}^{-1}$. The consequence of application of humid air

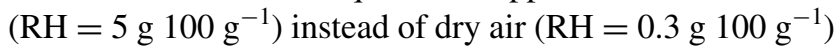
was lower value of MR index. This indicates that the amount of products of high molecular weight which are water soluble, have a brown color and are measured by the absorbance at $420 \mathrm{~nm}$ is lower in case of beans roasted with humid air.

When the air flow rate was ramped during roasting, MR index value has increased in cocoa beans roasted with dry air at $135{ }^{\circ} \mathrm{C}$ in comparison with the value of this index indicated in roasted beans at fixed conditions. Roasting with dry air at $150{ }^{\circ} \mathrm{C}$ resulted in a greater increase in the MR index despite the shorter time of thermal processing with an exception of processing at $150{ }^{\circ} \mathrm{C}$ when the air flow rate was decreased from 1 to $0.5 \mathrm{~m} \mathrm{~s}^{-1}$. Cocoa beans roasted with humid air under the latter conditions of temperature and flow rate contained higher MR index than those roasted with dry air. In this case, roasting with humid air was by 5 min longer compared to roasting with dry air

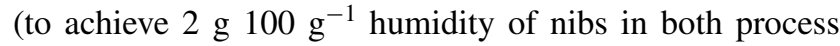
variants). This relatively small difference in time of processing is thought to be insufficient to cause substantial changes in the composition of soluble brown compounds in cocoa beans.

Analysis of effects caused by changes in air flow rate during roasting (either from 1 to 0.5 or from 0.5 to $1 \mathrm{~m} \mathrm{~s}^{-1}$ ) shows that MR index was higher when the rate was reduced from 1 to $0.5 \mathrm{~m} \mathrm{~s}^{-1}$. It suggests that the higher air flow rate in the first phase of roasting stimulated pigments formation. 
When the variable parameter was temperature of roasting air, MR index was higher when it was increased from 135 to $150{ }^{\circ} \mathrm{C}$, presumably because of the longer processing of cocoa beans compared to the variant in which the temperature was decreased from 150 to $135{ }^{\circ} \mathrm{C}$. In both variants of temperature profiles, MR index was higher dur-

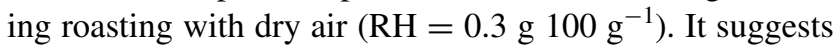
that dry air and low water content inside the cocoa beans stimulate browning reactions.

When the variable parameter was relative humidity of roasting air, MR index was higher when roasting was conducted at the lower temperature $\left(135^{\circ} \mathrm{C}\right)$. At the higher temperature $\left(150{ }^{\circ} \mathrm{C}\right)$, brown substances produced during roasting are presumably less soluble in water than those formed at lower temperature which leads to lower brown color intensity in extracts.

The MR index in all the tested samples of roasted cocoa beans ranged between 0.86 and 2.48 (Fig. 6). It achieved the highest values in samples roasted under the following conditions:

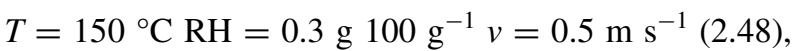

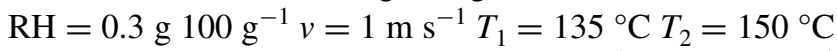

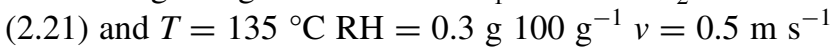
(2.12). The comparison of this index values with results of the other color measurements shows that they are consistent for samples with the deepest brown color with an exception of values of F1/F3 ratio (Fig. 5).

\section{Quantification of total polyphenols}

The content of polyphenols in cocoa beans depends not only on the species of bean, but also on the country of origin, growing conditions as well as the conditions and the time of fermentation and subsequent drying of the beans. For example, Hii et al. [12] studied the effect of drying methods of beans after fermentation in wooden boxes on a total polyphenol content. This parameter, depending on the method of drying, ranged from 61.81 to $88.45 \mathrm{mg} \mathrm{g}^{-1}$. In these studies, freeze-dried samples contained the highest polyphenol content due to the inactive enzymatic activity. In the sun-dried beans, the lowest total polyphenol content was determined due to the lower temperature profile and longer drying process. Bonvehi and Coll [5] studied changes in polyphenol content of six different samples of cocoa beans during the 8 days of fermentation. They observed that the concentration of above-mentioned compounds stabilized after about 6 days and averaged $43.1 \mathrm{mg} \mathrm{g}^{-1}[5,12,14,31]$. Further processing stage of cocoa beans, in particular alkalization (60\% loss of all polyphenols) and roasting cause further loss of polyphenols. For example, roasting of beans at a temperature of $127-150{ }^{\circ} \mathrm{C}$ for $30 \mathrm{~min}$ results in $60 \%$ reduction in procyanidins, while raising the temperature to $180{ }^{\circ} \mathrm{C}$ results in $80 \%$ degradation of these compounds [1, 14].

In the present study, total polyphenol contents in raw and roasted cocoa beans (processed under tested conditions) are shown in Fig. 7. Raw cocoa beans contained approximately

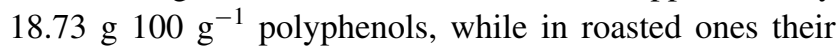

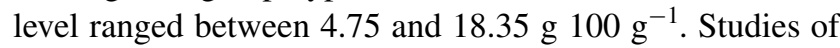
changes in the concentration of different fractions of polyphenols in un-roasted and roasted $\left(120{ }^{\circ} \mathrm{C}, 45 \mathrm{~min}\right)$ cocoa liquor were conducted by Misnawi, Jinap, Jamilah and Nazamid [21]. The total reduction in these components was about $20 \%$ of polyphenols of all fractions. In the present study, reduction in the concentration of polyphenols in cocoa beans was different, namely from about 2 to about $75 \%$, depending on the roasting conditions.

When roasting was conducted under constant conditions, more polyphenols were left in cocoa beans treated at the higher air flow rate $\left(1 \mathrm{~m} \mathrm{~s}^{-1}\right)$ compared to those processed at $v=0.5 \mathrm{~m} \mathrm{~s}^{-1}$. Also processing with humid air (instead of dry air) and the temperature of $135{ }^{\circ} \mathrm{C}$ (instead of $150{ }^{\circ} \mathrm{C}$ ) were favorable for their level.

Lesser losses of polyphenols were observed in cocoa beans processed under variable conditions, in particular at $\mathrm{RH}=5 \mathrm{~g} 100 \mathrm{~g}^{-1}$ and $135^{\circ} \mathrm{C}$ when the air flow rate was decreased from 1 to $0.5 \mathrm{~m} \mathrm{~s}^{-1}$. Cocoa beans roasted under the latter conditions contained almost the same amount

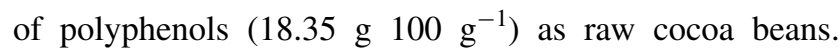
When the variable parameter was the air flow rate (either decreased from 1 to 0.5 or elevated from 0.5 to $1 \mathrm{~m} \mathrm{~s}^{-1}$ ) or the temperature of humid air was ramped from 135 to $150{ }^{\circ} \mathrm{C}$, more polyphenols remained after roasting compared to processing with dry air. By contrast, a decrease in temperature of humid air from 150 to $135^{\circ} \mathrm{C}$ caused higher

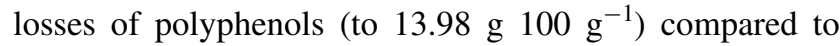

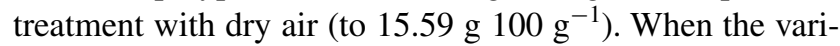
able parameter was the relative air humidity, more polyphenols remained after roasting at the lower temperature like after roasting under constant conditions.

Estimation of the relationship between changes in total polyphenols level and roasting conditions showed that the higher process temperature and the lower $\mathrm{RH}$ and $\mathrm{v}$ stimulate degradation of these substances in Forastero cocoa beans from Togo. The highest concentration of health promoting polyphenols, determined as total polyphenols by $\mathrm{F}-\mathrm{C}$ method, was found in cocoa beans processed with humid air at $135{ }^{\circ} \mathrm{C}$ when the air flow rate was decreased from 1 to $0.5 \mathrm{~m} \mathrm{~s}^{-1}$. The presence of polyphenols in cocoa beans affects their color, and the darker beans contain more polyphenols. The highest total polyphenol level was found in the sample containing the highest amount of pigments, which were quantified through extraction (the high OD value for II and III variants of extraction conditionsFig. 2) also when it was followed by separation of pigment 


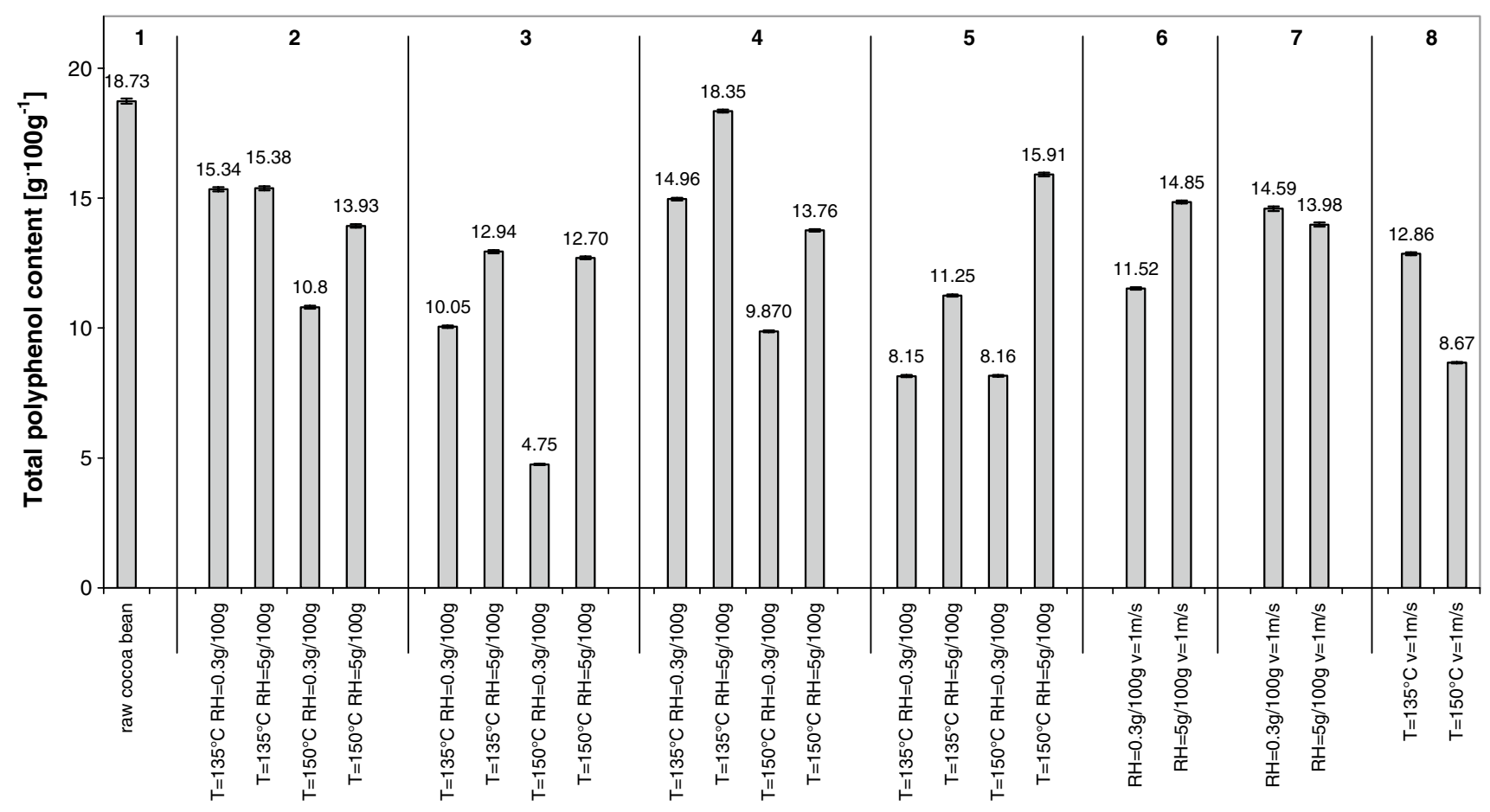

1: raw cocoa bean 2: $v=1 \mathrm{~m} / \mathrm{s}$ 3: $v=0.5 \mathrm{~m} / \mathrm{s}$ 4: $\mathrm{v}_{1}=1 \mathrm{~m} / \mathrm{s} \mathrm{v}_{2}=0.5 \mathrm{~m} / \mathrm{s}$ 5: $\mathrm{v}_{1}=0.5 \mathrm{~m} / \mathrm{s}_{2}=1 \mathrm{~m} / \mathrm{s}$ 6: $T_{1}=135^{\circ} \mathrm{C}_{2}=150^{\circ} \mathrm{C}$

7: $\mathrm{T}_{1}=150^{\circ} \mathrm{C} \mathrm{T}_{2}=135^{\circ} \mathrm{C}$ 8: $\mathrm{RH}_{1}=5 \mathrm{~g} / 100 \mathrm{~g} \mathrm{RH}_{2}=0.3 \mathrm{~g} / 100 \mathrm{~g}$

Fig. 7 Total polyphenols content (determined by F-C method) as a function of cocoa beans roasting conditions; mean $\pm \mathrm{SD} ; n=9$

fractions and determination of the browning index describing the progress of roasting process $(\mathrm{F} 1 / \mathrm{F} 3=0.32$ which is close to the border value of 0.3 -Fig. 5) and color parameters measurements in system CIE L*a*b* (one of the highest values of $b$, which corresponds to the content of yellow pigments-Table 2, No XVI).

\section{Conclusion}

Presented in this work methods of color determination have been used to estimate the progress of browning of cocoa beans during their roasting. Results of assays of color parameters are consistent in many cases in terms of distinguishing between most or least roasted cocoa beans. The choice of analytical method enabling estimation of the color of cocoa beans depends on information which has to be revealed. In many cases, using a CIE L*a*b* system or spectrophotometric assay determining the content of Maillard reactions products allows for estimation of the color change of roasted beans. Other cases require more advanced analytical methods, such as extraction method combined with the colorimetric determination of fractions of pigments. Among extraction methods, the one presented in paragraph 2.4. Methods (variant II) may be recommended mainly due to its simplicity and used chemicals.

Results obtained within the scope of this study provide evidence that in general, cocoa beans of Forastero variety from Togo have better color parameters when their roasting is conducted at $135{ }^{\circ} \mathrm{C}$ (compared to results of roasting at $150{ }^{\circ} \mathrm{C}$ ) regardless of the method of color determination. Both under constant and variable process parameters, an increase in the relative humidity of roasting air from 0.3

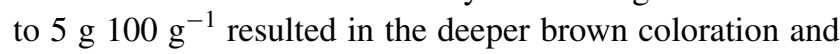
higher total polyphenols content of cocoa beans. Only the values of MR index are inconsistent with this conclusion.

Conducted studies used to select roasting method takes into account the change of color in the desired direction. When roasted cocoa beans are used in fabrication of chocolate, the CIE L*a*b* method is suitable for determination of their color because roasting conditions should ensure low values of parameter L. In contrast, roasted cocoa beans which are used to produce powdered cocoa that is consumed in the form of brews have to contain extractable pigments ensuring the suitable color of drinks. In the latter case, the progress of roasting should be monitored by pigment extraction. 
Acknowledgments The authors wish to thank Polish Ministry of Science and High Education for financial support of research within the scope of development project No. N N312 102038.

\section{Conflict of interest None.}

Compliance with Ethics Requirements This article does not contain any studies with human or animal subjects.

Open Access This article is distributed under the terms of the Creative Commons Attribution License which permits any use, distribution, and reproduction in any medium, provided the original author(s) and the source are credited.

\section{References}

1. Andres-Lacueva C, Monagas $\mathrm{M}$, Khan N, Izquierdo-Pulido $\mathrm{M}$, Urpi-Sarda M, Permanyer J et al (2008) Flavanol and flavonol contents of cocoa powder products: influence of the manufacturing process. J Agric Food Chem 56:3111-3117

2. Biehl B, Voigt J (1996) Biochemistry of chocolate flavor precursors. International Cocoa Conference, Salvador, p 30

3. Bodart M, de Peñarada R, Deneyer A, Flamant G (2008) Photometry and colorimetry characterization of materials in daylighting evaluation tools. Build Environ 43:2046-2058

4. Bonaparte A, Alikhani Z, Madramootoo C, Raghavan V (1998) Some quality characteristics of solar-dried cocoa beans in St. Lucia. J Sci Food Agric 76:553-558

5. Bonvehi JS, Coll FV (1997) Evaluation of bitterness and astringency of polyphenolic compounds in cocoa powder. Food Chem 60:365-370

6. Bonvehi JS, Coll FV (2002) Factors affecting the formation of alkylpyrazines during roasting treatment in natural and alkalinized cocoa powder. J Agric Food Chem 50:3743-3750

7. Cassidy A, Hanley B, Lamuela-Raventos RM (2000) Isoflavones, lignans and stilbenes-origins, metabolism and potential importance to human health. J Sci Food Agric 80:1044-1062

8. Cros E, Villeneuve F, Vincent JC (1982) Recherche d'un indice de fermentation du cacao. II Estimation de la matière colorante rouge des fèves de cacao. Café Cacao Thé XXVI(2):109-112

9. Demir AD, Celayeta JMF, Cronin K, Abodayeh K (2002) Modelling of kinetics of colour in hazelnuts during air roasting. J Food Eng 55:283-292

10. Fogliano V, Verde V (1999) Method for measuring antioxidant activity and its application to monitoring the antioxidant capacity of wines. J Agric Food Chem 47:1035-1040

11. Hawlader MNA, Perera CO, Tian M (2006) Properties of modified atmosphere heat pump dried foods. J Food Eng 74:392-401

12. Hii CL, Law CL, Cloke M, Suzannah S (2009) Thin layer kinetics of cocoa and dried product quality. Biosyst Eng 102:153-161

13. Izzo HV, Ho CT (1992) Ammonia effects Maillard chemistry of an extruded autolyzed yeast extract: pyrazine aroma generation and brown color formation. J Food Sci 57(657-659):674

14. Jalil AMM, Ismail A (2008) Polyphenols in cocoa and cocoa products: is there a link between antioxidant properties and health? Molecules 13:2190-2219
15. Krysiak W (2006) Influence of roasting conditions on coloration of roasted cocoa beans. J Food Eng 77:449-453

16. Krysiak W, Motyl-Patelska L (2006) Effects of air parameters on changes in temperature inside roasted cocoa beans. Acta Agrophysica 132(7):113-128

17. Krysiak W, Iciek J, Motyl-Patelska L (2003) Wpływ warunków prażenia na wybrane właściwości fizykochemiczne ziarna kakaowego (Influence of roasting conditions on selected physicochemical properties of cocoa beans). Inz Chem Procesowa 24:509-523

18. Lee S-Y, Yoo S-S, Lee M-J, Kwon I-B, Pyun Y-R (2001) Optimization of nibs roasting in cocoa bean processing with lotte-better taste and color process. Food Sci Biotechnol 10:286-293

19. Michalska A, Zieliński H (2007) Produkty reakcji Maillarda w żywności (Maillard reactions products in food). Zywn-Nauk Technol Ja 2:13

20. Misnawi Jinap S, Jamilah B, Nazamid S (2003) Effects of incubation and polyphenol oxidase enrichment on colour, fermentation index, procyanidins and astringency of unfermented and partly fermented cocoa beans. Int J Food Sci Technol 38:285-295

21. Misnawi Jinap S, Jamilah B, Nazamid S (2005) Changes in polyphenol ability to produce astringency during roasting of cocoa liquor. J Sci Food Agric 85:917-924

22. Nebesny E, Rutkowski J (1998) Effect of roasting and secondary fermentation on cacao bean enrichment. Pol J Food Nutr Sci 48:437-444

23. Oliviero T, Capuano E, Cammerer B, Fogliano V (2009) Influence of roasting on the antioxidant activity and $\mathrm{hmf}$ formation of cocoa bean model systems. J Agric Food Chem 57:147-152

24. Özdemir M, Devres YO (2000) Analysis of color development during roasting of hazelnuts using response surface methodology. J Food Eng 45:17-24

25. Polish Standard (1998). Ziarno kakaowe. Pobieranie próbek i metody badań (Cocoa bean. Sampling and testing methods). PN-A-76101

26. Puziah H, Jinap S, Sharifah KSM, Asbi A (1998) Changes in free amino acids, peptide-N, sugar and pyrazine concentration during cocoa fermentation. J Sci Food Agric 78:535-542

27. Ramiro E, Franch A, Castellote C, Perez-Cano FJ, Permanyer J, Izquierdo-Pulido M, Castell M (2005) Flavonoids from Theobroma cacao down-regulate inflammatory mediators. J Agric Food Chem 53:8506-8511

28. Rocha AMCN, Morais AMMB (2003) Shelf life of minimally processed apple (cv. Jonagored) determined by colour changes. Food Control 14:13-20

29. Saltini R, Akkerman R, Frosch S (2013) Optimizing chocolate production through traceability: a review of the influence of farming practices on cocoa bean quality. Food Control 29:167-187

30. Wallace TC, Giusti M (2011) Selective removal of the violet color produced by anthocyanins in procyanidin-rich unfermented cocoa extracts. J Food Sci 76:C1010-C1017

31. Wollgast J, Anklam E (2000) Review on polyphenols in Theobroma cacao: changes in composition during the manufacture of chocolate and methodology for identification and quantification. Food Res Int 33:423-447

32. Yen W-J, Wang B-S, Chang L-W, Duh P-D (2005) Antioxidant properties of roasted coffee residues. J Agric Food Chem 53:2658-2663 